\title{
32. CRETACEOUS CALCAREOUS NANNOFOSSIL BIOSTRATIGRAPHY OF SITES 761, 762, AND 763, EXMOUTH AND WOMBAT PLATEAUS, NORTHWEST AUSTRALIA ${ }^{1}$
}

\author{
Timothy J. Bralower ${ }^{2}$ and William G. Siesser ${ }^{3}$
}

\begin{abstract}
Three sites drilled during Leg 122, Site 761 on the Wombat Plateau and Sites 762 and 763 on the Exmouth Plateau, provide a composite Cretaceous section ranging in age from Berriasian to Maestrichtian. Together, these sites contain an apparently complete, expanded Aptian-Maestrichtian record. Consistently occurring and moderately well-preserved nannofossil assemblages allow reasonably high biostratigraphic resolution. Our data indicate that traditional middle and Upper Cretaceous nannofossil biozonations are not entirely applicable in this region. In this investigation, we compare in detail the relative ranges of key Cretaceous nannofossil markers in the eastern Indian Ocean and in sections from Europe and North Africa. We have determined which previously used events are applicable, and which additional markers have biostratigraphic utility in this region. Significant differences in Campanian-Maestrichtian assemblages exist between the more northern Site 761 and Sites 762 and 763 . Such differences are surprising, considering that these sites are only separated by $3^{\circ}$ of latitude. We interpret them as marking a strong thermal gradient over the Exmouth Plateau region. Other results include the recovery of an expanded Albian-Cenomanian sequence containing a mixture of Austral and Tethyan floras, which will enable correlation of biozonations established for these two realms; the recovery of two condensed but apparently complete Cenomanian-Turonian boundary sections; correlation of Upper Cretaceous calcareous nannofossil biostratigraphy with magneto- and foraminifer stratigraphy; and correlation of portions of the Barrow Group equivalents to the Berriasian and Valanginian stages.
\end{abstract}

\section{INTRODUCTION}

The Exmouth Plateau located off northwest Australia represents a classic passive continental margin. One of the major objectives of Ocean Drilling Program (ODP) Leg 122 was to investigate the development of this margin through its pre-, syn-, and post-rift stages. Two sites were drilled in the central part of the Exmouth Plateau and a transect of four sites was drilled on the Wombat Plateau, a marginal horst on the northeast corner of the major structure.

Sediments of Cretaceous age compose a major portion of the total recovery and include: (1) pre-rift strata deposited in deltaic, fluvial, and marginal marine environments (Exon et al., this volume); (2) syn-rift sediments deposited in a juvenile ocean basin (Bralower, this volume; von Rad and Thurow, this volume); and (3) post-rift strata deposited in hemipelagic and pelagic environments (von Rad et al., this volume; Haq et al., this volume). These post-rift sediments are the major subject of this investigation.

Three sites from Leg 122, Site 761 on the Wombat Plateau and Sites 762 and 763 on the Exmouth Plateau (Fig. 1), provide a composite Cretaceous section ranging in age from Berriasian to Maestrichtian. Collectively, these sites contain an apparently complete, expanded Aptian-Maestrichtian record. Predominantly moderately well-preserved nannofossil assemblages occur throughout most of the sections allowing reasonably high biostratigraphic resolution. Preliminary shipboard investigations (Haq, von Rad, O'Connell, et al., 1990) indicated that traditional middle and particularly Upper Cre-

\footnotetext{
${ }^{1}$ von Rad, U., Haq, B. U., et al., 1992. Proc. ODP, Sci. Results, 122: College Station, TX (Ocean Drilling Program).

${ }^{2}$ Department of Geology, Florida International University, University Park, Miami, FL 33199, U.S.A. (Current address: Department of Geology, University of North Carolina, Chapel Hill, NC 27599-3315, U.S.A.) U.S.A.

${ }^{3}$ Department of Geology, Vanderbilt University, Nashville, TN 37235,
}

taceous nannofossil biozonations were not entirely applicable in this region. One of the major objectives of this investigation is to analyze in more detail the similarities and differences in the relative ranges of key Cretaceous nannofossil markers in the eastern Indian Ocean and in stratotype, parastratotype, and other sections from Europe and North Africa.

Nannofossil biostratigraphic investigation of these sections has led to the following highlights: (1) age calibration of portions of the Neocomian Barrow Group-equivalent sediments (Holes 762C, 763B, and 763C), (2) an expanded Albian-Cenomanian section with well-preserved Austral and Tethyan floras allowing calibration of high- and low-latitude zonation schemes (Hole 763B), (3) two Cenomanian-Turonian boundary sections (Holes $762 \mathrm{C}$ and $763 \mathrm{C}$ ), (4) an expanded upper Santonian-Maestrichtian section cored at two sites (Holes 761B, and 762C), (5) an almost complete Cretaceous/Tertiary boundary (Hole 761C; Pospichal and Bralower, this volume), and (6) correlation of Upper Cretaceous calcareous nannofossil biostratigraphy with foraminifer and magnetostratigraphy (Holes 761B and 762C). This report will focus on these highlights. Several topics have not been investigated in detail and will be the subject of future publications. These include paleogeography, taxonomy of particular nannofossil lineages, and more detailed high-resolution stratigraphy of particular intervals.

\section{SITES AND SECTIONS}

Site $761\left(16^{\circ} 44^{\prime} \mathrm{S}, 115^{\circ} 32^{\prime} \mathrm{E}\right)$ is situated at a water depth of $2168 \mathrm{~m}$ on the Wombat Plateau (Fig. 1). Two holes (761B and 761C) were drilled; in the former, $199 \mathrm{~m}$ of sediment were recovered from $286 \mathrm{~m}$ penetrated, and in the latter, $72 \mathrm{~m}$ of sediment were recovered from $437 \mathrm{~m}$ penetrated. The Cretaceous/Tertiary boundary was encountered at 175.9 meters below seafloor (mbsf). The upper part of the Cretaceous sedimentary column at this site consists of $64 \mathrm{~m}$ of chalk of Albian to Maestrichtian age. Beneath this are two separate units of Berriasian-Valanginian age deposited in juvenile ocean conditions. The upper unit consists of $15 \mathrm{~m}$ of light to 


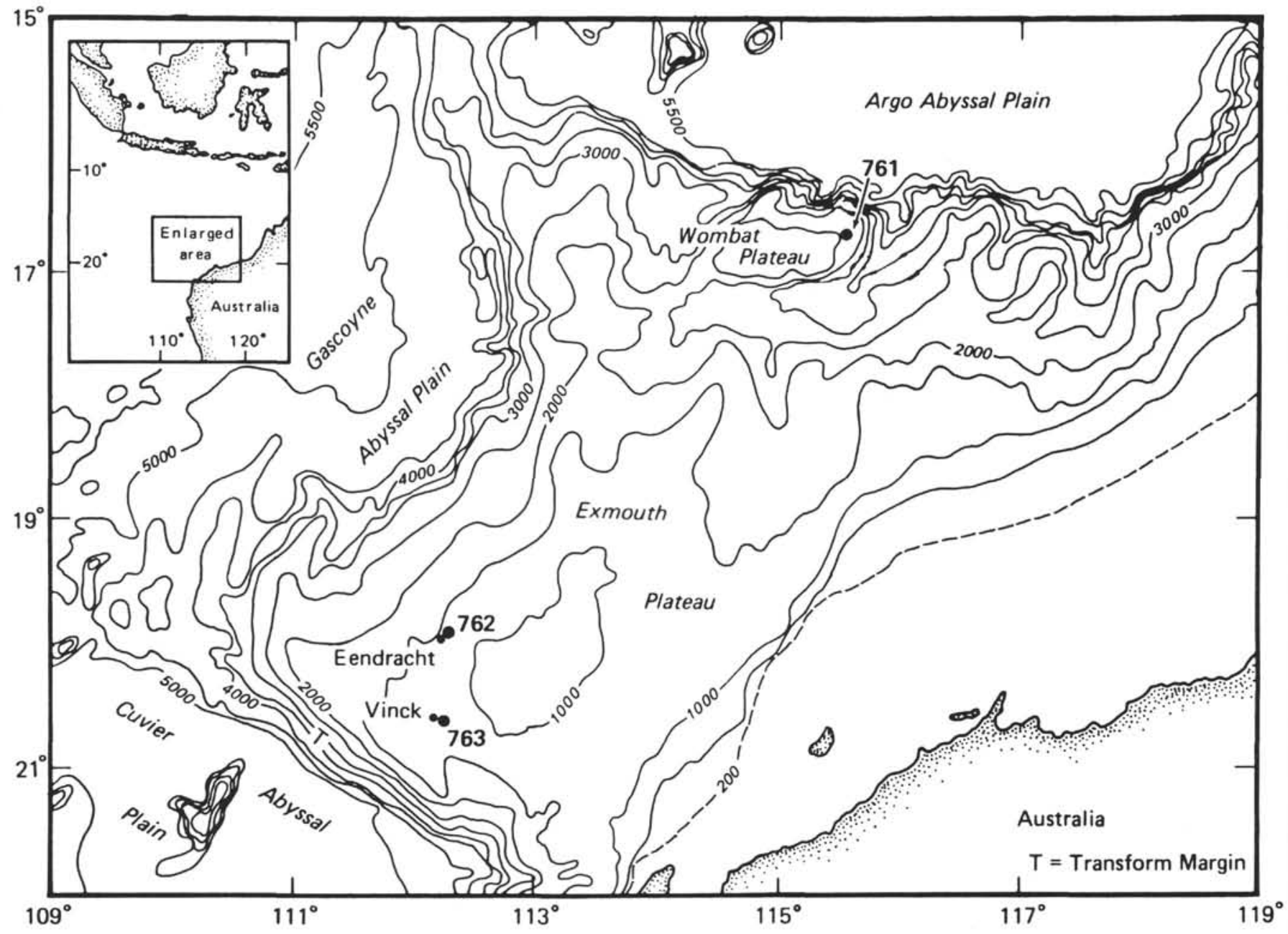

Figure 1. Location of Sites 761, 762, and 763 on the Exmouth Plateau, northwest Australia. Bathymetry in meters.

dark yellowish brown calcisphere nannofossil chalk with several discrete bentonite layers. The lower unit is composed of $4 \mathrm{~m}$ of yellowish brown to dark brown ferruginous sandstone. This unit contains numerous belemnite guards as well as thin lenses enriched in coccoliths.

Site $762\left(19^{\circ} 53^{\prime} \mathrm{S}, 112^{\circ} 15^{\prime} \mathrm{E}\right)$ lies at a water depth of $1360 \mathrm{~m}$ on the central Exmouth Plateau (Fig. 1). Cretaceous sediment was recovered from one hole $(762 \mathrm{C})$ and $535 \mathrm{~m}$ were retrieved of 770 $\mathrm{m}$ penetrated. The Cretaceous/Tertiary boundary was encountered at 55 mbsf and is characterized by a hiatus of brief duration. The Cretaceous section consists of $284 \mathrm{~m}$ of hemipelagic-pelagic interbedded white to light green-gray chalk and green-gray calcareous claystone of Albian-Maestrichtian age. These sediments overlie $10 \mathrm{~m}$ of dark gray to black calcareous claystone, the Muderong Shale equivalent, which is of Hauterivian to early Aptian age and reflects the restricted oceanic phase of the young proto-Tethys. The base of this hole consists of black to dark gray silty claystone, the Barrow Group-equivalent sediments of late Berriasian to early Hauterivian age, as determined by palynostratigraphy (Brenner, this volume, chapter 23). This latter unit was deposited in deltaic and marginal marine sedimentary environments.

Site $763\left(20^{\circ} 35^{\prime} \mathrm{S}, 112^{\circ} 12^{\prime} \mathrm{E}\right)$ is situated at a water depth of $1368 \mathrm{~m}$ also on the central Exmouth Plateau (Fig. 1). Cretaceous sediments were recovered in two holes, $763 \mathrm{~B}$ and $763 \mathrm{C}$.
The Cretaceous/Tertiary boundary was encountered at 247 mbsf and represents a hiatus of approximately $25 \mathrm{~m} . \mathrm{y}$. between the Eocene and late Campanian. Some $275 \mathrm{~m}$ of sediment of late Berriasian to late Campanian age were penetrated in Hole 763B. This consists of $139 \mathrm{~m}$ of hemipelagic-pelagic light green chalk of early Turonian to late Campanian age, $184 \mathrm{~m}$ of hemipelagic Albian-Cenomanian greengray calcareous claystone, $53 \mathrm{~m}$ of black silty claystone of Hauterivian to early Aptian age, the Muderong Shale-equivalent sediments, and $38 \mathrm{~m}$ of Barrow Group equivalents, dark gray silty claystone of middle Berriasian to early Hauterivian age. Hole $763 \mathrm{C}$ penetrated $376 \mathrm{~m}$ silty claystone of middlelate Berriasian age, the Barrow Group equivalents, which, as at Site 762 , is only partly marine.

In this report, we discuss the Cretaceous calcareous nannofossil biostratigraphy of Holes $761 \mathrm{~B}, 762 \mathrm{C}$ and $763 \mathrm{~B}$, the thickest and most fossiliferous sections recovered. General nannofossil biostratigraphic results of much shorter (Holes 760A, 761C, $764 \mathrm{~A}$, and 764B) and less fossiliferous (Hole 763C) sections are given in Haq, von Rad, O'Connell, et al. (1990). Individual elements of Cretaceous nannofossil stratigraphy of Hole 761C are discussed in Bralower (this volume; juvenile oceanic sediments and their assemblages and stable isotopes) and Pospichal and Bralower (this volume; Cretaceous/Tertiary boundary nannofossil assemblages in Hole 761C). 


\section{TECHNIQUES}

This investigation is based on the study of 42 samples from Hole 761B, 191 samples from Hole 762C, and 181 samples from Hole 763B. One to three samples were taken per section depending on the stratigraphic importance of the interval or the required resolution. Smear slides were prepared of all samples using standard preparation methods. Because nannofossils are the major component of most samples, no concentration techniques were employed. All samples were inspected briefly in the light microscope and the best preserved sample per section was chosen for detailed biostratigraphic investigations. The combined light microscope (LM)-scanning electron microscope (SEM) technique of Thierstein et al. (1972) was used to study selected samples in an ISI DS-130 SEM at the University of Miami. The taxonomy of most species observed is standard and described in more detail by various authors (e.g., Gartner, 1969; Thierstein, 1973; Wise and Wind, 1977; Perch-Nielsen, 1985; Covington and Wise, 1987; Crux, 1989). However, there are a few problems that deserve discussion and these are dealt with in the Appendix, where a full list of the identified taxa is presented.

Thickly concentrated smear slides were prepared so that even the rarest of occurrences could be noted. Relative abundance of nannofossils was determined in the following fashion: a species was determined as abundant if, on average, more than 10 specimens could be observed in a field of view at $1000 \times$ magnification; common if one to 10 specimens could be observed in each field; few if one specimen or more could be observed in every 10 fields of view, and rare if, on average, one specimen could not be observed in 10 fields. Preservation of nannofossils ranges from poor to good in the investigated sections and the etching and overgrowth parameters of Roth (1978) were used to describe the degree of alteration. Special attention was paid to samples in critical stratigraphic intervals, especially near the ends of species ranges, where slides were observed for several hours.

\section{RESULTS}

Detailed range charts of nannofossil taxa in Holes 761B, $762 \mathrm{C}$, and 763B are illustrated in back-pocket Tables 1, 2, and 3 , respectively. These charts are based on the study of one sample per section in most intervals, exceptions being the poorly fossiliferous Barrow Group-equivalent sediments in Holes $762 \mathrm{C}$ and $763 \mathrm{~B}$ where several samples were studied in most sections, but only the fossiliferous ones are reported. In the post-Turonian section of Hole 763B, our investigation is based on one sample in each alternate section. Far more attention was paid to the ranges of potential markers than to forms with little or no demonstrated biostratigraphic utility. The ranges of the former taxa as reported in Tables 1-3 (back pocket) are therefore much more continuous than those of the latter. The sub-bottom depths of these potential markers are tabulated in Table 4 for the three holes. A high proportion of events lie within "cat-walk" (shipboard, noncurated) corecatcher samples. This could be a result of two factors. First, in intervals of poor recovery, these samples represent the only material from a wide interval and therefore have a higher probability of containing more events than the other sections. Second, this material may be washed down from sections above. For this latter reason, the meter levels of appearance events lying in core-catcher samples are given for the next overlying occurrence.

\section{ZONATION}

There have been many different studies of Cretaceous calcareous nannofossil biostratigraphy over the last three decades. In the Upper Cretaceous interval, one of the first zonations proposed was by Cepek and Hay (1969) based on several North American sections. Further developments in taxonomy and the study of stratotype sections in Europe and Deep Sea Drilling Project (DSDP) cores led others to modify this original scheme. The zonations of Thierstein $(1971,1973)$ and Manivit et al. (1977) have been shown to be useful for the Lower and middle Cretaceous, respectively.

Two schemes, which serve the entire Cretaceous, have been most widely referenced in DSDP/ODP studies. The Sissingh (1977) zonation is largely based upon stratotype and parastratotype sequences in Europe, while the Roth (1978) scheme is developed upon the results of DSDP investigations. These two schemes therefore provide a useful framework for other investigations. Individual zonations proposed by other authors (e.g., Martini, 1976; Verbeek, 1977; Perch-Nielsen, 1977; Crux, 1982) have been utilized quite often, however, most of these were based on the results of one or few sections and therefore do not have the overall applicability of the Sissingh (1977) and Roth (1978) schemes. Because of the unsuitability of an individual zonation, certain authors have made a point of using a mixture of different zonations (e.g., Stradner and Steinmetz, 1984; Perch-Nielsen, 1985). Finally, other studies have been based entirely on less formal biohorizons (e.g., Thierstein, 1976; 1977) or a combination of zones and biohorizons (e.g., Bralower, 1988).

One of the most interesting results of our investigation is that neither of the commonly utilized Cretaceous calcareous nannofossil zonations, Sissingh (1977) or Roth (1978), is entirely applicable for the sections studied. Three major problems hinder the application of these zonations; variable taxonomic concepts, the rarity of important markers and differences in the order of events. These problems are most acute for the post-Cenomanian interval.

Differences in taxonomic concepts are not a significant reason for the inapplicability of zonations, especially that of Roth (1978) who used concepts similar to ours. A few disparities do arise in the Sissingh (1977) scheme, in particular with the two species of Reinhardtites, $R$. anthophorus, and $R$. levis. This particular taxonomic problem is discussed in the Appendix. A few species utilized by these other authors are too rare for consistent ranges to be developed. These include Tetralithus obscurus, Lucianorhabdus maleformis, Marthasterites furcatus, and Ceratolithoides aculeus.

The most severe problem, however, is the inconsistency in the order of marker events within our sections and between them and the zonation schemes. Biohorizon order is fairly consistent between Holes 762C and 763B on the central Exmouth Plateau, but rather different between these holes and Wombat Plateau Hole 761B (Table 4). This intriguing problem will be discussed in detail in a later section. Because of the apparent time-transgressiveness of events, we have chosen not to define a new Cretaceous zonation for the Indian Ocean basin based on our results until these disparities have been resolved.

Since both Sissingh (1977) and Roth (1978) zonations are partially applicable in the sections investigated, we compare our results to both of them. Figure 2 illustrates a tabulation of potential marker events which could be most accurately determined in our sections, and a comparison of these events with these two zonations. Because we have been unable to define several of the zonal markers accurately in our sections, we have combined many of the zones of Sissingh (1977) and Roth (1978). However, we are able to define some of their individual zones in the sections investigated in the Aptian to Maestrichtian interval. In other intervals, in addition to the use of combined zones, we rely on the use of biohorizons. The 
order of these events has been determined in Holes $762 \mathrm{C}$ and $763 \mathrm{~B}$ as these sections are thicker, more complete, and compare more favorably with one another than with Hole 761B. The two zonations (Sissingh, 1977; Roth, 1978) show an equal amount of applicability in the sections investigated. Overall, however, our results compare well to the biohorizon scheme of Thierstein (1977), which was based entirely on earlier drilling in the Indian Ocean, although this scheme was not very detailed.

Zonal and non-zonal events are of varying reliability as a result of biostratigraphic and taxonomic factors. Problems include taxonomic gradation between different species, rarity of forms, and facies or paleobiogeographic factors which cause marked abundance fluctuations and possible nonsynchroneity of events in different sections. In Table 5, we tabulate events which are affected by these problems and those events which we feel are the most reliable.

The pre-Aptian sections investigated are characterized by depauperate nannofossil assemblages of unusual composition. These sediments were deposited in marginal marine environments and therefore lack many of the zonal markers used in pelagic and hemipelagic sections. We rely on the occurrence of individual markers and other evidence to date this material, and this is discussed in detail in a later section.

Summary diagrams showing the correlation of zones and biohorizons to the three sections investigated are illustrated in Figure 3 (Hole 761B), Figure 4 (Hole 762C), and Figure 5 (Hole 763B). These diagrams include a column indicating the stratigraphic continuity of individual sections, condensed intervals, and unconformities. The stratigraphic ramifications of our biostratigraphy are discussed below individually for each hole.

To illustrate the difficulties in application of published zonations, and so that our results can be more easily compared to those of other investigations, the following is a zone-by-zone discussion of the correlation of the Sissingh (1977) zonation in the sections observed. We have chosen the Sissingh (1977) zonation for this analysis rather than the scheme of Roth (1978) because the former scheme has been more frequently applied in other Indian Ocean Cretaceous investigations.

\section{CC26 Nephrolithus frequens Zone}

Definition. Interval from the first to the last occurrence of Nephrolithus frequens.

Authors. Cepek and Hay (1969).

Age. Latest Maestrichtian.

Hole 761B. Sections 122-761B-21X-4 to 122-761B-23X-1.

Hole 762C. Sections $122-762 C-43 X-1$ to $122-762 C-47 X-4$.

Hole 763B. Not present.

Comments. The base of this zone is clearly time-transgressive between the two sites. In Hole 761B, the first occurrence of $N$. frequens correlates with the first occurrence of Micula murus (Table 4; Fig. 3), whereas in Hole $762 \mathrm{C}$ this event lies below the first occurrence of Lithraphidites quadratus (Table 4; Fig. 4). The last occurrence of Petrarhabdus copulatus and first occurrences of Lithraphidites quadratus and $L$. praequadratus lie in this interval in Hole $762 \mathrm{C}$ (Table 4).

\section{CC25 Arkhangelskiella cymbiformis Zone Taxonomic/cnt}

Definition. Interval from the last occurrence of Reinhardtites levis to the first occurrence of Nephrolithus frequens.

Author. Sissingh (1977).

Age: Late Maestrichtian.

Hole 761B. Sections 122-761B-23X-1 to 122-761B-24X-1.

Hole 762C. Sections 122-762C-47X-4 to $122-762 \mathrm{C}-47 \mathrm{X}-\mathrm{CC}$.

Hole 763B. Not present.

Comments. The top of this zone is clearly time-transgressive between the two sites (see comments under Zone CC26). Determina- tion of the last occurrence of $R$. levis in the material examined should not be affected by our difficulties in distinguishing this species from $R$. anthophorus (see Appendix for details) as this level marks the last occurrence of the genus as a whole. The last occurrence of Petrarhabdus copulatus and first occurrences of Lithraphidites quadratus and $L$. praequadratus lie in this interval in Hole 761B (Table 4).

\section{CC24 Reinhardtites levis Zone}

Definition. Interval from the last occurrence of Tranolithus phacelosus to the last occurrence of Reinhardtites levis.

Author. Sissingh (1977).

Age. Early Maestrichtian.

Hole 761B. Indefinable.

Hole 762C. Indefinable.

Hole 763B. Not present.

Comments. $T$. phacelosus is a synonym of $T$. orionatus. The last occurrence of $T$. orionatus lies in Section 122-761B-23X-4 and in Section 122-762C-47X-5, which are above the first occurrence of $N$. frequens (Table 4). Thus, although the markers occur, the reverse order of events from the Sissingh (1977) zonation means that this interval does not exist in the sections studied.

\section{CC23 Tranolithus phacelosus Zone}

Definition. Interval from the last occurrence of Reinhardtites anthophorus to the last occurrence of Tranolithus phacelosus.

Author. Sissingh (1977).

Age. Late Campanian to early Maestrichtian.

Hole 761B. Indefinable.

Hole $762 \mathrm{C}$. Indefinable.

Hole 763B. Not present.

Comments. We have been unable to differentiate consistently between $R$. anthophorus and $R$. levis in the material examined (see Appendix for full discussion); hence, the range reported for the former species, the last occurrence of which defines the base of this zone, may not be entirely accurate.

\section{CC22 Tetralithus trifidus Zone}

Definition. Interval from the first occurrence of Tetralithus trifidus to the last occurrence of Reinhardtites anthophorus.

Author. Sissingh (1977).

Age. Late Campanian.

Hole 761B. Base in Section 122-761B-25X-CC

Hole 762C. Base in Section 122-762C-54X-5.

Hole 763B. Base in Section 122-763B-8X-CC.

Comments. We cannot define the top of this zone for the same reason as in Zone CC23. Numerous useful biohorizons lie in the interval between the base of this zone and the top of Zone CC24 (Table 4; Figs. 2-5). These include the last occurrences of Broinsonia parca, Eiffellithus eximius, and Quadrum trifidum, and the first occurrence of Arkhangelskiella cymbiformis. The first occurrence of Petrarhabdus copulatus lies in this interval in Hole 761B, but in Zone CC21 in Hole 762C. The uppermost Cretaceous sediments recovered in Hole 763B lie in this zone.

\section{CC21 Tetralithus nitidus Zone}

Definition. Interval from the first occurrence of Tetralithus nitidus to the first occurrence of Tetralithus trifidus.

Author. Sissingh (1977).

Age. Late Campanian.

Hole 761B. Sections 122-761B-25X-CC to 122-761B-26X-CC.

Hole 762C. Sections 122-762C-54X-5 to $122-762 C-57 X-1$.

Hole 763B. Sections 122-763B-8X-CC to 122-763B-10X-CC.

Comments. We combine $T$. nitidus and Quadrum sissinghii in $Q$. gothicum as it is not possible to differentiate between these taxa in overgrown condition. Perch-Nielsen (1985) differentiated between the first occurrence of $Q$. gothicum at the Santonian-Campanian boundary and the first occurrence of $Q$. sissinghii in the late Campanian. In Holes $762 \mathrm{C}$ and 763B, the first occurrence of $Q$. gothicum lies close to $50 \mathrm{~m}$ above the first occurrence of Broinsonia parca which is a more traditional definition of the Santonian-Campanian boundary. Thus, we believe that the range of $Q$. gothicum obtained here is similar to that of $T$. nitidum given by Sissingh (1977). The first occurrence of Petrarhabdus copulatus lies in this interval in Hole $762 \mathrm{C}$ (Table 4). 
Table 4. Sub-bottom depths (m) of nannofossil events.

\begin{tabular}{|c|c|c|c|}
\hline Nannofossil Event & $\begin{array}{c}\text { Hole } \\
761 B\end{array}$ & $\begin{array}{l}\text { Hole } \\
762 \mathrm{C}\end{array}$ & $\begin{array}{l}\text { Hole } \\
763 B\end{array}$ \\
\hline Last Cretaceous species & 175.97 & 554.80 & 247.00 \\
\hline base Micula murus & 190.01 & 565.80 & \\
\hline base Lithraphidites quadratus & 192.60 & 578.30 & \\
\hline base Lithraphidites praequadratus & 199.09 & 587.81 & \\
\hline top Petrarhabdus copulatus & 194.47 & 589.32 & \\
\hline base Nephrolithus frequens & 190.01 & 597.19 & \\
\hline top Tranolithus orionatus & 194.47 & 598.80 & \\
\hline top Reinhardtites levis & 199.09 & 602.00 & \\
\hline top Broinsonia parca & 205.04 & 602.00 & 247.18 \\
\hline top Eiffellithus eximius & 208.20 & 608.26 & 247.18 \\
\hline top Quadrum trifidum & 208.61 & 612.79 & \\
\hline base Arkhangelskiella cymbiformis & 205.10 & 614.80 & \\
\hline base Quadrum trifidum & 215.20 & 665.29 & 252.70 \\
\hline base Petrarhabdus copulatus & 214.63 & 668.80 & \\
\hline base Quadrum gothicum & 220.30 & 687.80 & 275.50 \\
\hline top Lithastrinus grillii & 213.09 & 708.41 & 304.31 \\
\hline base Broinsonia parca & 227.59 & 744.74 & 315.30 \\
\hline base Parhabdolithus regularis & & 744.74 & 323.00 \\
\hline base Ceratolithoides aculeus & 220.30 & 757.30 & \\
\hline base Lucianorhabdus cayeuxï & & 771.30 & 323.00 \\
\hline top Eprolithus moratus & 219.60 & 780.30 & 337.29 \\
\hline base Lithastrinus grillii & & 782.50 & 337.29 \\
\hline top Eprolithus floralis & & 785.00 & 346.76 \\
\hline base Micula staurophora & & 786.20 & 353.30 \\
\hline base Marthasterites furcatus & & & 361.00 \\
\hline base Kamptnerius magnificus & & 804.80 & 364.10 \\
\hline base Quadrum gartneri & & 809.93 & 382.20 \\
\hline base Eiffellithus eximius & & 810.63 & 382.20 \\
\hline top Microstaurus chiastius & & 810.91 & 389.50 \\
\hline base Corollithion kennedyi & & 819.25 & 424.29 \\
\hline base Eiffellithus turriseiffelii & & 824.30 & 457.80 \\
\hline top Sollasites falklandensis & & & 484.50 \\
\hline base Axopodorhabdus albianus & & & 486.32 \\
\hline base Percivalia hauxtonensis & & & 486.32 \\
\hline base Tranolithus orionatus & & & 494.28 \\
\hline base Hayesites albiensis & & & 517.80 \\
\hline base Sollasites falklandensis & & & 527.27 \\
\hline base Prediscosphaera columnata & & 830.65 & 528.75 \\
\hline base Cribrosphaerella primitiva & & & 543.70 \\
\hline base Vagalapilla matalosa & & 834.50 & 622.50 \\
\hline
\end{tabular}

The interval from the top of this zone down to Zone $\mathrm{CC} 8$ is condensed, missing or poorly recovered in Hole 761B (Fig. 3).

\section{CC20 Ceratolithoides aculeus Zone}

Definition. Interval from the first occurrence of Ceratolithoides aculeus to the first occurrence of Tetralithus nitidus.

Author. Sissingh (1977).

Age. Early Campanian.

Hole 761B. Top in Section 122-761B-26X-CC.

Hole 762C. Top in Section 122-762C-57X-1.

Hole 763B. Top in Section 122-763B-10X-CC.

Comments. Ceratolithoides aculeus is rare in the material examined, and it is therefore not possible to obtain an accurate range for this taxon. In Hole 762C, a few specimens have been observed below the first occurrence of Broinsonia parca, which defines the base of Zone $\mathrm{CC18}$, indicating that the range of $C$. aculeus may be slightly different here from the locations studied by Sissingh (1977).

\section{CC19 Calculites ovalis Zone}

Definition. Interval from the last occurrence of Marthasterites furcatus to the first occurrence of Ceratolithoides aculeus.

Author. Sissingh (1977).

Age. Early Campanian.

Hole 761B. Indefinable.

Hole 762C. Indefinable.

Hole 763B. Indefinable.

Comments. In Holes 761B and 762C, both species have been observed too rarely to provide reliable ranges. In Hole 763B, $M$. furcatus occurs consistently, but its last occurrence lies below the first occurrence of Broinsonia parca, which defines the base of the zone below.
CC18 Aspidolithus parcus Zone

Definition. Interval from the first occurrence of Aspidolithus parcus to the last occurrence of Marthasterites furcatus.

Author. Sissingh (1977).

Age. Early Campanian.

Hole 761B. Base in Section 122-761B-27X-1.

Hole 762C. Base in Section 122-762C-63X-1.

Hole 763B. Base in Section 122-763B-15X-2.

Comments. The first occurrence of $B$. parca is a very reliable event. The last occurrence of Lithastrinus grillii lies in the interval between the base of this zone and the top of Zone CC20 (Figs. 3-5; Table 4).

\section{CC17 Calculites obscurus Zone}

Definition. Interval from the first occurrence of Calculites obscurus to the first occurrence of Aspidolithus parcus.

Author. Sissingh (1977).

Age. Early Campanian.

Hole 761B. Top in Section 122-761B-27X-1.

Hole 762C. Top in Section 122-762C-63X-1.

Hole 763B. Top in Section 122-763B-15X-2.

Comments. $C$. obscurus was not observed in the samples examined.

\section{CC16 Lucianorhabdus cayeuxii Zone}

Definition. Interval from the first occurrence of Lucianorhabdus cayeuxii to the first occurrence of Calculites obscurus.

Author. Sissingh (1977).

Age. Late Santonian.

Hole 761B. Base in Section 122-761B-27X-CC.

Hole 762C. Base in Section 122-762C-66X-CC.

Hole 763B. Base in Section 122-763B-15X-CC.

Comments. $C$. obscurus was not observed in the samples examined. The first occurrence of $L$. cayeuxii appears to be a reliable event. The first occurrences of Ceratolithoides aculeus and Parhabdolithus regularis lie in the interval between the base of this zone and the top of Zone $\mathrm{CC} 17$ (Table 4).

\section{CC15 Reinhardtites anthophorus Zone}

Definition. Interval from the first occurrence of Reinhardtites anthophorus to the first occurrence of Lucianorhabdus cayeuxii.

Author. Sissingh (1977).

Age. Early Santonian.

Hole 761B. Top in Section 122-761B-27X-CC.

Hole 762C. Top in Section 122-762C-66X-CC

Hole 763B. Top in Section 122-763B-15X-CC.

Comments. We have been unable to differentiate consistently between $R$. anthophorus and related zygoliths. Moreover, in all three sites, the lowest Reinhardtites occurs below the first occurrence of Micula staurophora which defines the base of the zone below.

\section{CC14 Micula staurophora Zone}

Definition. Interval from the first occurrence of Micula staurophora to the first occurrence of Reinhardtites anthophorus.

Author. Sissingh (1977).

Age. Late Coniacian to early Santonian.

Hole 761B. Not present.

Hole 762C. Base in Section 122-762C-70X-CC

Hole 763B. Base in Section 122-763B-19X-2.

Comments. See comments under Zone CC15. The last occurrences of Eprolithus moratus and E. floralis and the first occurrence of Lithastrinus grillii lie in the interval between the base of this zone and the top of Zone CC15.

\section{CC13 Marthasterites furcatus Zone}

Definition. Interval from the first occurrence of Marthasterites furcatus to the first occurrence of Micula staurophora.

Author. Sissingh (1977).

Age. Early Coniacian.

Hole 761B. Not present.

Hole 762C. Top in Section 122-762C-70X-CC.

Hole 763B. Top in Section 122-763B-19X-2. 
STAGE EVENT

SISSINGH ROTH

(1977) (1978)

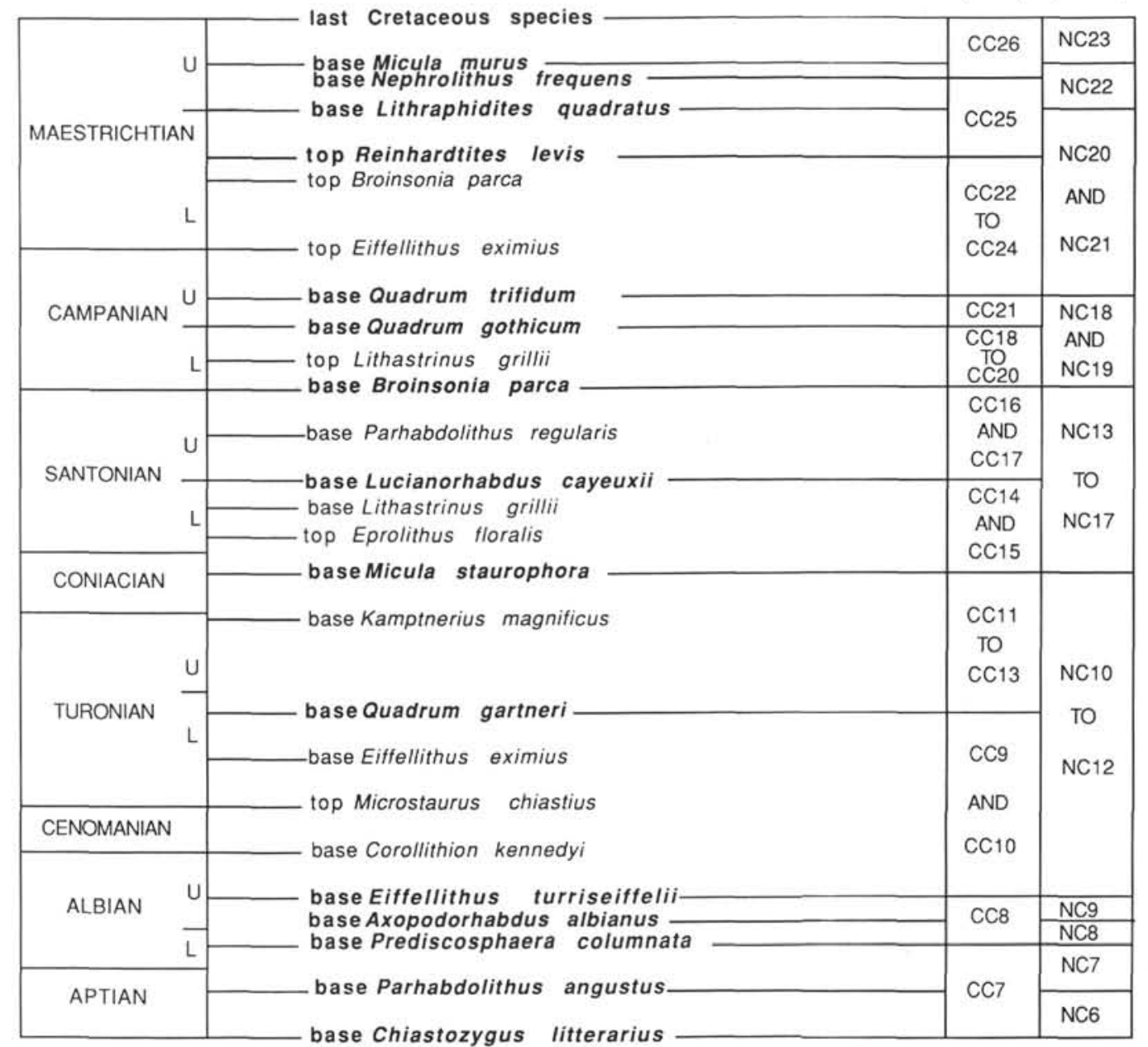

Figure 2. Correlation of biohorizons used in this investigation with Sissingh (1977) and Roth (1978) zonations and with Cretaceous stage boundaries. Biohorizons shown in bold are zonal markers.

Comments. $M$. furcatus has been observed too rarely to provide a reliable range.

\section{CC12 Lucianorhabdus maleformis Zone}

Definition. Interval from the first occurrence of Lucianorhabdus maleformis to the first occurrence of Marthasterites furcatus.

Author. Sissingh (1977).

Age. Late Turonian to early Coniacian.

Hole 761B. Not present.

Hole 762C. Indefinable.

Hole 763B. Indefinable.

Comments. Both taxa have been observed too rarely to provide reliable ranges.

\section{CC11 Tetralithus pyramidus Zone}

Definition. Interval from the first occurrence of Tetralithus pyramidus to the first occurrence of Lucianorhabdus maleformis.

Author. Sissingh (1977).

Age. Early Turonian.

Hole 761B. Not present.

Hole 762C. Base in Section 122-762C-75X-1.

Hole 763B. Base in Section 122-763B-22X-CC.

Comments. $L$. maleformis has been observed too rarely to provide a reliable range. The first occurrence of $T$. pyramidus $(Q \cdot$ gartneri $)$ lies in the condensed interval just above the Cenomanian-Turonian boundary in Holes 762C and 763B. The first occurrence of Marthasterites furcatus lies in the interval between the base of this zone and the top of Zone CC13 in Hole 763B. The first occurrence of Kamptnerius magnificus lies in this same interval in Holes $762 \mathrm{C}$ and 763B. Clearly the interval including this zone and Zone CC10 is very condensed in Holes 762C and 763B (Figs. 4 and 5).

\section{CC10 Microrhabdulus decoratus Zone}

Definition. Interval from the first occurrence of Microrhabdulus decoratus to the first occurrence of Tetralithus pyramidus.

Author. Sissingh (1977).

Age. Late Cenomanian.

Hole 761B. Not present.

Hole 762C. Top in Section 122-762C-75X-1.

Hole 763B. Top in Section 122-763B-22X-CC.

Comments. $M$. decoratus has a very patchy occurrence in the early part of its range. In most sections it extends below the first occurrence of $T$. pyramidus $(Q$. gartneri). The fact that this is not the case here may be related to the very condensed nature of the CenomanianTuronian boundary in the sites observed.

\section{CC9 Eiffellithus turriseiffelii Zone}

Definition. Interval from the first occurrence of Eiffellithus turriseiffelii to the first occurrence of Microrhabdulus decoratus.

Author. Sissingh (1977).

Age. Middle Albian to early Cenomanian.

Hole 761B. Not present.

Hole 762C. Base in Section 122-762C-77X-4.

Hole 763B. Base in Section 122-763B-30X-2. 
Table 5. Reliability of nannofossil events determined.

\begin{tabular}{|c|c|}
\hline \multicolumn{2}{|c|}{$\begin{array}{l}\text { base Micula murus } \\
\text { top Petrarhabdus copulatus } \\
\text { top Reinhardtites levis } \\
\text { top Broinsonia parca } \\
\text { top Eiffellithus eximius } \\
\text { top Quadrum trifidum } \\
\text { base Quadrum trifidum } \\
\text { base Petrarhabdus copulatus } \\
\text { base Quadrum gothicum } \\
\text { top Lithastrinus grillii } \\
\text { base Broinsonia parca } \\
\text { base Parhabdolithus regularis } \\
\text { top Eprolithus moratus } \\
\text { base Lithastrinus grillii } \\
\text { top Eprolithus floralis } \\
\text { base Micula staurophora } \\
\text { base Kamptnerius magnificus } \\
\text { base Quadrum gartneri } \\
\text { base Eiffellithus eximius } \\
\text { top Microstaurus chiastius } \\
\text { base Corollithion kennedyi } \\
\text { base Eiffellithus turriseiffelii } \\
\text { base Axopodorhabdus albianus } \\
\text { base Percivalia hauxtonensis } \\
\text { base Tranolithus orionatus } \\
\text { base Hayesites albiensis } \\
\text { base Sollasites falklandensis } \\
\text { base Prediscosphaera columnata } \\
\text { base Cribrosphaerella primitiva } \\
\text { base Vagalapilla matalosa }\end{array}$} \\
\hline B. Problematic events & \\
\hline $\begin{array}{l}\text { base Lithraphidites quadratus } \\
\text { base Lithraphidites praequadratus } \\
\text { base Arkhangelskiella cymbiformis } \\
\text { base Reinhardtites levis }\end{array}$ & $\begin{array}{l}\text { Exact measurement required } \\
\text { Exact measurement required } \\
\text { The ultimate BAG species! } \\
\text { Transition with } R \text {. anthophorus and } \\
\text { Z. elegans }\end{array}$ \\
\hline \multicolumn{2}{|l|}{$\begin{array}{l}\text { top Tranolithus orionatus } \\
\text { base Ceratolithoides aculeus } \\
\text { base Marthasterites furcatus } \\
\text { top Sollasites falklandensis }\end{array}$} \\
\hline \multicolumn{2}{|c|}{ 3. Paleobiogeographic/preservational difficulties } \\
\hline $\begin{array}{l}\text { base Nephrolithus frequens } \\
\text { base Ceratolithoides aculeus } \\
\text { base Lucianorhabdus cayeuxii }\end{array}$ & $\begin{array}{l}\text { Obviously diachronous } \\
\text { Variable abundance between sites } \\
\text { Highly variable abundance }\end{array}$ \\
\hline
\end{tabular}

Comments. The base of this zone can be accurately defined in all of the sites observed. The interval from the base of this zone to the top of Zone CC10 includes the first occurrences of Corollithion kennedyi and Eiffellithus eximius and the last occurrence of Microstaurus chiastius in Holes 762C and 763B (Table 4; Figs. 4 and 5).

\section{CC8 Prediscosphaera cretacea Zone}

Definition. Interval from the first occurrence of Prediscosphaera cretacea to the first occurrence of Eiffellithus turriseiffelii.

Author. Sissingh (1977).

Age. Early to middle Albian.

Hole 761B. Sections 122-761B-27X-CC to $122-761 \mathrm{~B}-28 \mathrm{X}-\mathrm{CC}$.

Hole 762C. Sections 122-762C-77X-4 to $122-762$ C-78X-2.

Hole 763B. Sections 122-763B-30X-2 to 122-763B-37X-5.

Comments. We differentiate $P$. columnata from $P$. cretacea. The base of this zone is given by the first occurrence of the former species as Sissingh (1977) did not differentiate these taxa. Numerous biohorizons lie in this interval in Hole 763B (Table 4). These include the last occurrence of Sollasites falklandensis and the first occurrences of Axopodorhabdus albianus, Percivalia hauxtonensis, Tranolithus orionatus, Hayesites albiensis, and Sollasites falklandensis.

\section{CC7 Chiastozygus litterarius Zone}

Definition. Interval from the first occurrence of Chiastozygus litterarius to the first occurrence of Prediscosphaera cretacea.

Author. Sissingh (1977).

Age. Early Aptian to early Albian.

Hole 761B. Top in Section 122-761B-28X-CC.

Hole 762C. Top in Section 122-762C-78X-2.

Hole 763B. Top in Section 122-763B-37X-5.

Comments. The early Aptian interval in Holes $762 \mathrm{C}$ and 763B contains a low diversity nannoflora without the standard marker taxa. We use the first occurrence of Rucinolithus irregularis as a proxy for the first occurrence of Chiastozygus litterarius (Thierstein, 1973).

In conclusion, we rely on a combination of Sissingh (1977) and Roth (1978) zonation schemes and numerous less formal biohorizons. Further, more detailed study of critical intervals in these sequences and a compilation of data from other Indian Ocean Cretaceous sections will lead to development of a clearly required, more formal regional zonation scheme.

\section{STAGE BOUNDARY DEFINITIONS}

The problem of varying order of events between our sections and the commonly referenced zonations is not unique. A comparison of the order of the same events in four different schemes, Thierstein (1976, 1977), Sissingh (1977), Roth (1978), and PerchNielsen (1985) reveals a similar degree of disparity (Table 6). Of equal concern is the lack of agreement of the age assignment of individual markers. The age calibration of numerous events has been well determined in stratotype and parastratotype sections and is similar in different publications. However, there are still several other routinely used events which have widely varying age assignments, and these are not always a result of explicable taxonomic differences. Cases in point are the last occurrence of Lithastrinus grillii, and the first occurrences of Micula staurophora and Lucianorhabdus cayeuxii (Table 6). These problems are compounded by the fact that nannofossil events rarely exactly define Cretaceous stage boundaries with any precision.

Of 11 Cretaceous stage boundaries, it is only possible to define four with varying degree of precision using nannofossil biostratigraphy (Fig. 2) and even these definitions invoke arguments among different specialists. These boundaries and the definitions used here are: Barremian-Aptian (first occurrences of Chiastozygus litterarius and Rucinolithus irregularis (Thierstein, 1973)), Cenomanian-Turonian (last occurrence of Microstaurus chiastius (Bralower, 1988)), Santonian-Campanian (first occurrence of Broinsonia parca (Thierstein, 1976)), Campanian-Maestrichtian (last occurrence of Eiffellithus eximius (Thierstein, 1976)). In addition, we approximate the Albian-Cenomanian boundary by the first occurrence of Corollithion kennedyi although this event lies in the lowermost Cenomanian (Crux, 1982). Other Cretaceous stage boundaries can only be approximated by two boundary events, and in some cases the uncertainty is considerable (Fig. 2). In particular, the Coniacian is a very difficult stage to pin down.

\section{CRETACEOUS BIOSTRATIGRAPHY OF THE EXMOUTH PLATEAU}

Two sections investigated provide an apparently complete composite upper Aptian to upper Maestrichtian section. Hole $762 \mathrm{C}$ contains an apparently complete lower Turonian to upper Maestrichtian sequence, and Hole 763B provides an expanded upper Aptian to upper Cenomanian section. Certain intervals (e.g., the Cenomanian-Turonian boundary interval) are obviously condensed in both holes; however, the recovery of black shale layers and the boundary Whiteinella archaeocretacea foraminifer Zone (Wonders, this volume) indicate 


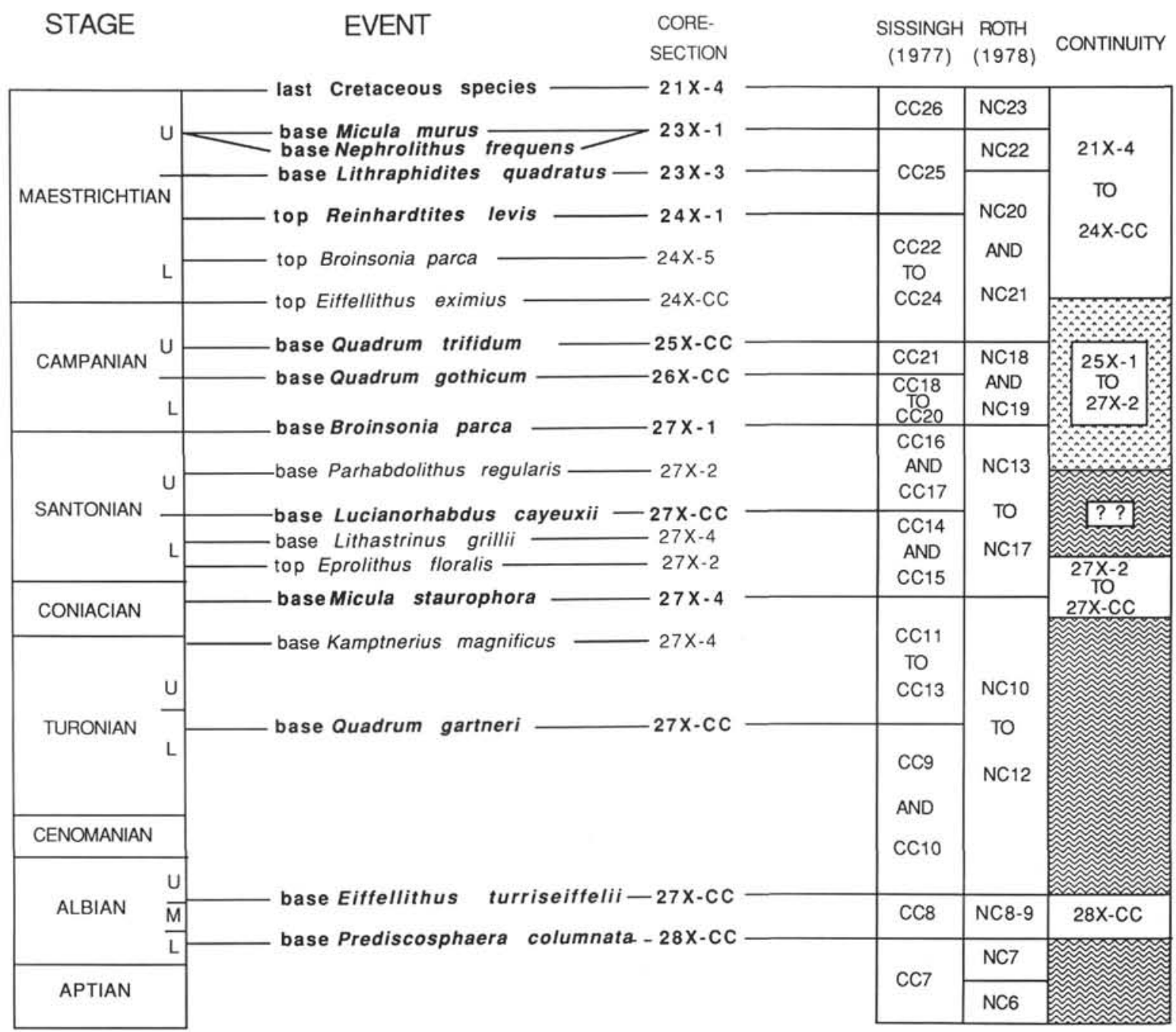

Figure 3. Calcareous nannofossil biostratigraphic summary of Hole 761B. See Figure 2 for explanation of events and zones. Wavy lines indicate stratigraphic distribution of hiatuses. Hachured symbol shows possible condensed section.

that the boundary is probably complete. In other intervals, particularly the upper Turonian to lower Santonian, biostratigraphic resolution is insufficient to adequately test the completeness of the section. These two holes provide the opportunity for a classic reference section for the Albian-Maestrichtian in the eastern Indian Ocean. They also provide a framework against which to interpret less complete sectionsfor example, the sequence recovered in Hole 761B. In the following, we summarize the nannofossil biostratigraphy of the three holes and its stratigraphic implications.

\section{Hole 762C}

An apparently complete lower Turonian to upper Maestrichtian section was recovered in Hole 762C (Table 2, back pocket; Fig. 4). Preservation of calcareous nannofossils is moderate throughout most of the hole with a slight deterioration downsection. Most samples contain evidence of etching and overgrowth. While this has not led to the preservation of fragile forms or an exceptionally high diversity, the markers are adequately preserved, and most of them have fairly continuous ranges. The lack of significant facies or preservation changes in most of this section also increases biostratigraphic reliability. Certain intervals, for example that sur- rounding the Cenomanian-Turonian boundary, contain poorly preserved nannofossils.

The Cretaceous/Tertiary boundary in Hole $762 \mathrm{C}$ lies in the upper part of Section 122-762C-43X-1. The sediments across this boundary are not firm and this boundary does not appear to be biostratigraphically complete. Paleocene nannofossil Zone NP1 is much thinner than at Site 761 (Siesser and Bralower, this volume). The upper Santonian to upper Maestrichtian section measures almost $200 \mathrm{~m}$ in this hole and is very expanded compared to Hole $761 \mathrm{~B}$. There do not appear to be any major gaps in this part of the section. The only events which coincide are the last occurrences of Broinsonia parca and Reinhardtites levis in Section 122-762C-47X-CC, and the first occurrences of Broinsonia parca and Parhabdolithus regularis in Section 122-762C-63X-1. It is possible that there are minor unconformities in these sections. The lower Santonian to upper Cenomanian part of the section appears to be less expanded, although we have no quantitative evidence for this statement and the biostratigraphic resolution in this part of the column is lower than that above. Nannofossil preservation starts to decline in the upper Turonian and decreases dramatically in Core $122-762 \mathrm{C}-75 \mathrm{X}$ near the Cenomanian-Turonian boundary, an observation that will be 


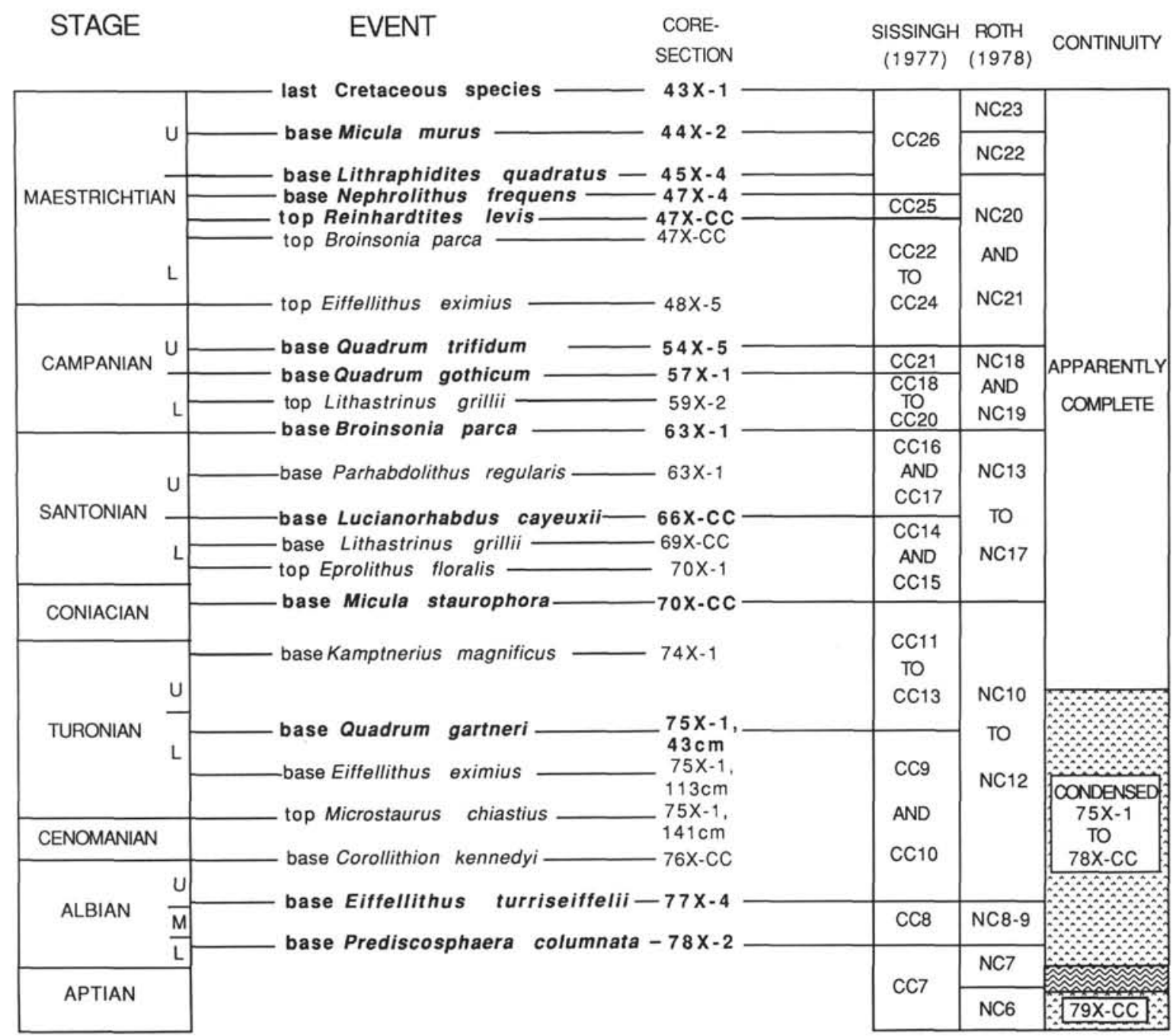

Figure 4. Calcareous nannofossil biostratigraphic summary of Hole 762C. For explanation of events, zones, and symbols, see Figures 2 and 3.

discussed in a later section. Preservation is poor in chalks in Cores 122-762C-76X to 122-762C-78X, which are of AlbianCenomanian age. The Muderong Shale-equivalent strata in Cores $122-762 \mathrm{C}-79 \mathrm{X}$ and $-80 \mathrm{X}$ were poorly recovered. Nannofossils in this unit are rare, of low diversity, and lack standard marker taxa. This unit had previously been assigned a late Barremian to early Aptian age based on the presence of Vagalapilla matalosa and the absence of later Aptian species such as Parhabdolithus angustus and Eprolithus floralis (Haq, von Rad, O'Connell, et al., 1990). However, V. matalosa has been in observed in sediments of known Valanginian age at Site 766 (Mutterlose, in press), thus considerably extending the range of this taxon and refuting our previous age assignment of the Muderong-equivalent sediments. Brenner (this volume, chapter 23) has determined an Hauterivian to early Aptian age for this unit based on palynostratigraphy. This early Aptian age is supported by nannofossil biostratigraphy. One sample from the "cat-walk" core catcher of Section $122-762 \mathrm{C}-78 \mathrm{X}-\mathrm{CC}$, which is within the Muderong Shale equivalent, as opposed to the chalk from the overlying core catcher, contains single specimens of Rucinolithus irregularis and Micrantholithus hoschulzii. The combination of these species indicate an early Aptian age (Thierstein, 1976). The age of the underlying Barrow Group equivalents will be discussed in detail in a later section.

Several layers of green claystone in Cores $122-762 \mathrm{C}-45 \mathrm{X}$ to -47X (middle Maestrichtian) contain unusually high abundances of the nannofossil genus Micula (species mainly $M$. staurophora). Although this species is extremely solution resistant (Thierstein, 1980), these sediments contain extremely low ratios of the solution resistant species Watznaueria barnesae to less resistant taxa. These occurrences, which appear to be "blooms,"' have also been reported from the Maestrichtian of Israel (Moshkovitz and Eshet, 1989). Other samples in this site contain unusual enrichments of the holococcolith species, Lucianorhabdus cayeuxii.

\section{Hole 763B}

A hiatus of about $30-\mathrm{m} . \mathrm{y}$. duration at the top of Core $122-763 \mathrm{~B}-8 \mathrm{X}$ is underlain by an apparently continuous upper Aptian/lower Albian to upper Campanian section (Table 3, back pocket; Fig. 5). The top of this section is upper Campanian based on the presence of Quadrum trifidum in Core 122-763B-8X. There is a possible unconformity in the interval near Section 122-763B-15X-CC in which the first occurrences of Parhabdolithus regularis and Lucianorhabdus cayeuxii coincide. These 
STAGE

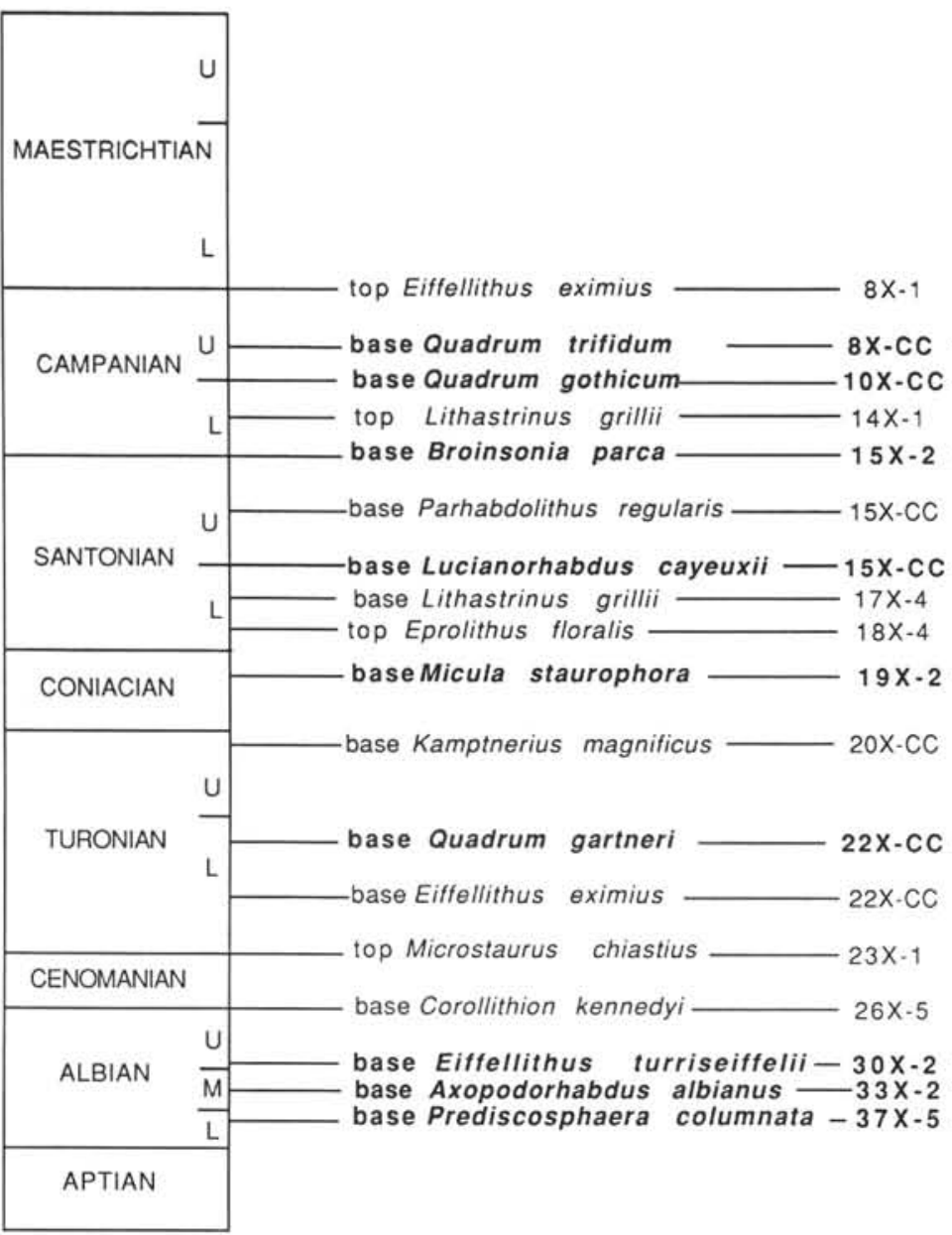

SISSINGH ROTH

(1977) (1978)

CONTINUITY

Figure 5. Calcareous nannofossil biostratigraphic summary of Hole 763B. For explanation of events, zones, and symbols, see Figures 2 and 3 .

two events are separated by $27 \mathrm{~m}$ in Hole $762 \mathrm{C}$ (Table 4); however, $L$. cayeuxii has a fairly patchy distribution in these sediments and appears to be facies dependent (Table 5). Nannofossil preservation at the top of this section is moderate, and as in Hole $762 \mathrm{C}$, this deteriorates downward toward the Cenomanian-Turonian boundary, which lies between Cores 122-763B$22 \mathrm{X}$ and $-23 \mathrm{X}$. The boundary interval is characterized by extremely poor preservation. One of the major features of this site is the recovery of an expanded Albian-Cenomanian section with well-preserved nannofossils. Assemblages from this material will be discussed in more detail in a later section. It is not possible to precisely date the oldest part of this section, as the AptianAlbian boundary cannot be defined on the basis of nannofossils. The range of Cribrosphaerella primitiva, the first occurrence of which lies in the late Aptian (Thierstein, 1976), extends down to Section 122-763B-39X-CC. However, nannofossil preservation deteriorates strongly below this level, precluding the determination of the true first occurrence of this species.

A more complete section of Muderong Shale-equivalent strata was recovered from this hole in Cores 122-763B-42X to 122-763B-47X. Sediments from Section 122-763B-43X-3 to $122-763 \mathrm{~B}-47 \mathrm{X}-\mathrm{CC}$ had been dated as late Barremian to early Aptian based on similar criteria to the same unit from Hole $762 \mathrm{C}$-the presence of Vagalapilla matalosa but absence of typical Aptian forms. However, as in Hole $762 \mathrm{C}$, this age is now uncertain and appears to be somewhat older, ranging from Hauterivian to early Aptian (Brenner, this volume, chapter 23). As in Hole $762 \mathrm{C}$, this unit contains an extremely low-diversity nannoflora with unusually high abundances of V. matalosa, V. stradneri, Biscutum constans, and Parhabdolithus asper. A few specimens of Broinsonia orthocancellata have been observed but the range of this species has not been well constrained. Similar assemblages have been observed from contemporaneous sediments from DSDP Sites 327 and 511 on the Falkland Plateau (Wise and Wind, 1977; Wise, 1983) and the low diversity of these assemblages are interpreted as reflecting deposition in a juvenile ocean basin. The age of the underlying Barrow Group equivalents will be discussed in detail in a later section.

\section{Hole 761B}

We discuss Hole 761B last because this is the least complete Cretaceous sequence and the results obtained from the other two sites help interpret the biostratigraphy of this section. The Cretaceous/Tertiary boundary in this hole lies in Section 122-761B-21X-4 at $128 \mathrm{~cm}$. This is a disturbed contact and is not as complete as the section recovered in Hole 761C (Pospichal and Bralower, this volume). No Micula prinsii 
Table 6. Age of nannofossil events in different time scales.

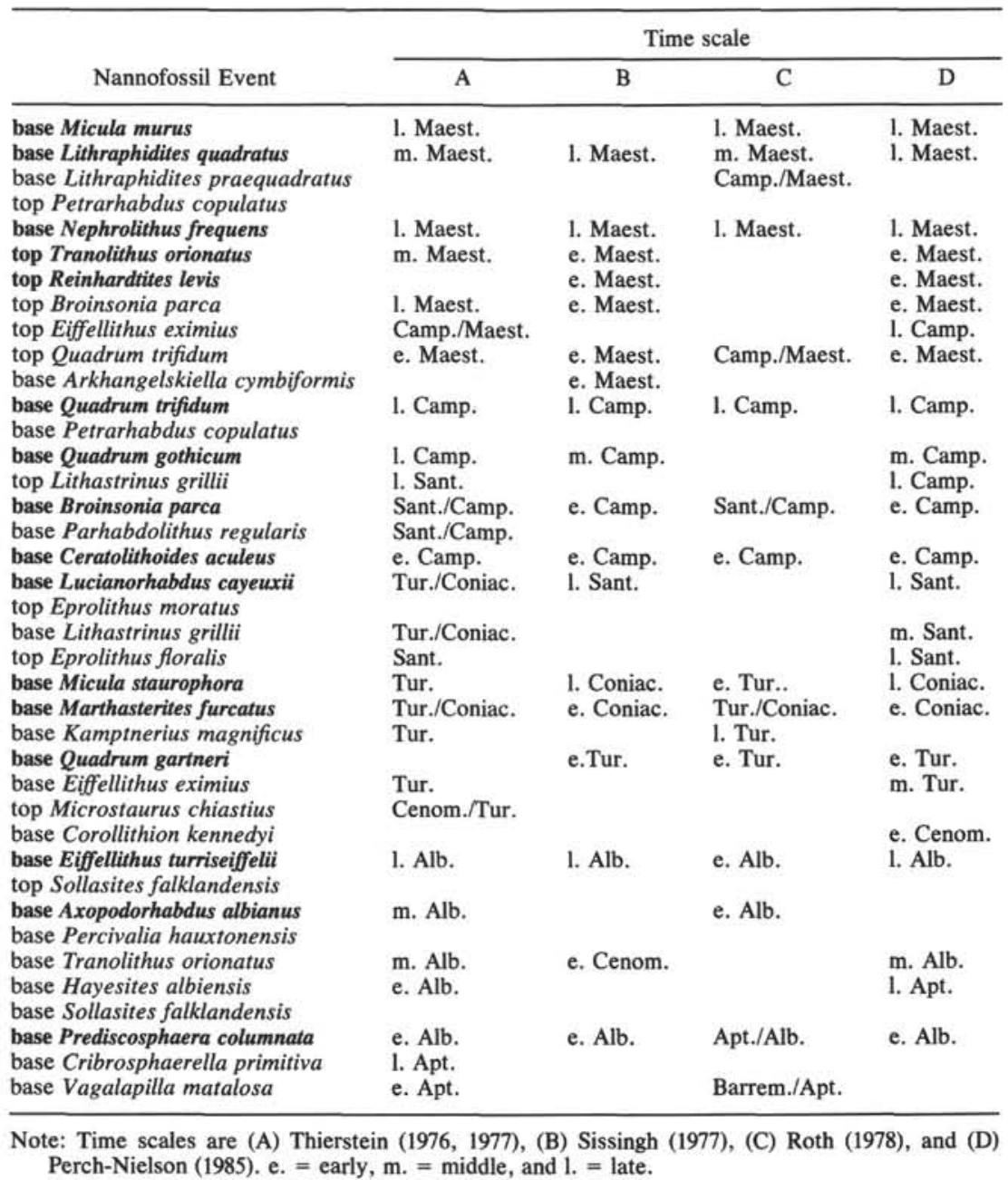

were observed at either this site or at Site 762, although the absence of this latest Maestrichtian taxon does not indicate that this interval is missing, as it has not been observed in other boundary sections which have been demonstrated to be complete. The Maestrichtian appears to be complete, or at least as far as can be interpreted with nannofossil biostratigraphy (Table 1, back pocket; Fig. 3). One interesting result is that the first occurrence of Nephrolithus frequens lies at a similar level to that of Micula murus, whereas in Hole $762 \mathrm{C}$ it lies some $32 \mathrm{~m}$ lower, below the first occurrence of Lithraphidites praequadratus. Other Upper Cretaceous events also appear to be slightly diachronous between the two sites (Table 4). We have concluded that the reasons for this diachroneity are largely paleoceanographic, and discuss this in more detail in the next section.

The remainder of Hole 761B below the Maestrichtian, which was poorly recovered, appears to be either condensed, or punctuated by unconformities (Fig. 3). We utilize the biostratigraphy developed in Holes $762 \mathrm{C}$ and $763 \mathrm{~B}$ to interpret the stratigraphy of this section. The Campanian is extremely thin, spanning only three cores, $122-761 \mathrm{~B}-25 \mathrm{X}$ to $-27 \mathrm{X}$. Much of the Santonian is missing, although a small section of Coniacian or early Santonian age exists between Sections 122-761B-27X-2 and -27X-CC (Fig. 3). Chalk recovered in Section 122-761B-28X-CC is of middle Albian age.

\section{DISCUSSION}

\section{Age Calibration of the Neocomian Barrow Group Equivalents}

The precise age of the Barrow Group-equivalent sediments drilled in Hole $762 \mathrm{C}$ is difficult to establish owing to the paucity of nannofossil markers in this unit (Table 2, back pocket). Numerous nannofossiliferous samples were found, however, and the presence of a few marker specimens has enabled the age of this unit to be loosely constrained. Palynostratigraphy provides much more definitive age information in the Barrow Group equivalents (Brenner, this volume, chapter 23). Section 122762C-82X-CC contains Cruciellipsis cuvillieri, Crucibiscutum salebrosum, and Diadorhombus rectus, and Section 122-762C$86 \mathrm{X}-\mathrm{CC}$ contains the former two markers. The ranges of these taxa overlap from the uppermost Ryazanian to the upper Hauterivian, but $C$. salebrosum shows a pronounced acme in the Valanginian in the North Sea region (e.g., Crux, 1989). D. rectus has been observed in the Berriasian to Aptian in well-preserved material, and has been used as a marker for the middle Valanginian, where its range is restricted in most sequences (Thierstein, 1976) within the Tubodiscus verenae (NK3) Zone (Bralower et al., 1989). Although not entirely equivocal, the above evidence suggests a middle Valanginian age for this part of the Barrow Group-equivalent sediments. 
A different nannofossil assemblage occurs in Samples $122-762 \mathrm{C}-88 \mathrm{X}-5,53 \mathrm{~cm}$, and 122-762C-91X-CC, $13 \mathrm{~cm}$, but this does not include age-diagnostic taxa (Table 2, back pocket). From the nannofossil biostratigraphy, it is not clear whether the Barrow Group-equivalent strata in Hole $762 \mathrm{C}$ were characterized by continuous sedimentation, or whether there is an intraformational hiatus, as suggested by the seismic stratigraphy (Boyd et al., this volume; Haq et al., this volume).

The Barrow Group equivalents were recovered in Holes $763 \mathrm{~B}$ and $763 \mathrm{C}$, and in this report we discuss the nannofossil biostratigraphy of both holes. The upper part of the Barrow Group equivalents recovered in Sections 122-763B-48X-4 to $-54 \mathrm{X}-\mathrm{CC}$ is late Berriasian to Valanginian in age. The age of the former interval is indicated by the presence of Tubodiscus verenae in Section 122-763B-54X-CC (Table 3, back pocket). Nannofossils occur in Hole 763C from Section 122-763C$4 \mathrm{R}-\mathrm{CC}$ to 122-763C-12R-CC. Species observed include Eiffellithus primus, Percivalia fenestrata, and Micrantholithus obtusus, which indicate that this interval is younger than middle Berriasian (Bralower et al., 1989).

The remainder of Hole $763 \mathrm{C}$ below this interval is largely barren of nannofossils, with the exception of the interval between Cores $122-763 \mathrm{C}-19 \mathrm{R}$ and $-21 \mathrm{R}$ in which we observed some extremely well-preserved assemblages. These lack characteristic markers and contain some very rare, and possibly undescribed, forms of the genus Stradnerlithus. The only taxon observed that has a well-defined, reported range is Micrantholithus brevis, which has been reported from the upper Ryazanian and lower Valanginian of the North Sea region (Jakubowski, 1987; Crux, 1989). As in Hole 762C, it is not possible to predict whether there are more than one unconformable sequences in Hole $763 \mathrm{C}$. The ages given by palynostratigraphy (Brenner, this volume, chapter 23) are once again more definitive, but are supported by the information obtained here.

\section{An Expanded Middle Cretaceous Temperate Nannofossil Biostratigraphy in Hole $763 \mathrm{~B}$}

An expanded late Aptian/early Albian to late Cenomanian section corresponding to the Gearle Siltstone unit was recovered in Hole 763B. This unit is predominantly composed of calcareous claystone or marl, and although excellent, the recovery is biscuited (regular horizons disturbed by drilling) and thus, not all of the material is useful. Sediments contain well-preserved temperate nannofloras with elements of both Austral and Tethyan assemblages. Study of this section therefore allows calibration of zonation schemes developed in high(e.g., Wise, 1983) and low-latitude (e.g., Thierstein, 1973) regions. Potential biostratigraphically useful markers from this interval have been tabulated in Tables 4-6. These include species that have abundance peaks in high-latitude regions: Cribrosphaerella primitiva, Sollasites falklandensis, Corollithion kennedyi, and Percivalia hauxtonensis. These taxa provide both first and last occurrence events in the middle Cretaceous. The range of $C$. primitiva is by far the most continuous, the other species having patchier distributions toward the ends of their ranges. Other Austral species with less clear biostratigraphic potential include: Broinsonia gammation (base), Octocyclus magnus (base and top), and Eiffellithus cf. E. eximius (base and top). Potentially useful species with a Tethyan or cosmopolitan distribution include the commonly used markers, Prediscosphaera columnata and Eiffellithus turriseiffelii (both bases), and also Axopodorhabdus albianus, Tranolithus orionatus (both bases), and Hayesites albiensis (base and top) (Tables 4-6). Other Tethyan/ Cosmopolitan events with less demonstrated potential include
Cribrosphaerella ehrenbergii (base), Eiffellithus trabeculatus (base), Corollithion signum (base), Rucinolithus irregularis (top), Broinsonia signata (base), Prediscosphaera spinosa (base), and Parhabdolithus achlyostaurion (base).

Although detailed counts of nannofossil assemblages have not been conducted, there do not appear to be any dramatic fluctuations in the relative abundances of taxa with Tethyan and Austral affinities. This would indicate that Site 763 was located in a fairly stable part of the temperate realm throughout the middle Cretaceous. The Austral part of the nannofloral assemblage apparently declined somewhat in the Cenomanian, as indicated by the low relative abundances of Lithraphidites acutum.

\section{Cenomanian-Turonian Boundary Sections, Sites 762 and 763}

The Cenomanian-Turonian boundary has been associated with an oceanwide anoxic event (Schlanger and Jenkyns, 1976; Schlanger et al., 1987). This is indicated by the occurrence of organic carbon-rich sediments near the boundary in numerous land and deep-sea sections. Two apparently complete Cenomanian-Turonian boundary sequences were recovered in Holes $762 \mathrm{C}$ and $763 \mathrm{C}$. In Hole 763B this boundary lies between Cores 122-763B-22X and -23X.

Dark shales were recovered in the Cenomanian-Turonian boundary interval in Holes $762 \mathrm{C}$ and $763 \mathrm{C}$. In Hole $762 \mathrm{C}$, dark brown shale occurs in Section 122-762C-75X-1, between 115 $\mathrm{cm}$ and $138 \mathrm{~cm}$. This interval has a transitional upper but a sharper lower boundary and has organic carbon contents less than $2 \%$. Shales are considerably more organic-rich in Hole $763 \mathrm{C}$, containing between $7 \%$ and $15 \%$ total organic carbon (TOC) (Haq, von Rad, O'Connell, et al., 1990). Two thin, organic-rich horizons occur in this hole in Section 122-763C$2 \mathrm{R}-1$, between 20 and $32 \mathrm{~cm}$ and between 60 and $63 \mathrm{~cm}$. These two organic-rich horizons are sandwiched within an interval of glauconitic claystone.

Calcareous nannofossil biostratigraphy indicates that the Cenomanian-Turonian boundary interval is extremely condensed in both holes. In Section 122-762C-75R-1, the last occurrence of Microstaurus chiastius occurs right below the brown shale horizon, and the first occurrence of Eiffellithus eximius lies right above this $23-\mathrm{cm}$-thick level. These two events occur in the opposite order in expanded CenomanianTuronian boundary sections in the North American Western Interior Basin and are separated by up to $7 \mathrm{~m}$ (Bralower, 1988). Poor nannofossil preservation occurs on both sides of the boundary with low nannofloral abundances. The Whiteinella archaeocretacea foraminifer Zone is only $43 \mathrm{~cm}$ thick in this hole (Wonders, this volume) whereas it is over 4 $\mathrm{m}$ thick in Western Interior sections (e.g., Leckie, 1985). In Hole $763 \mathrm{C}$, the last occurrences of numerous Cenomanian species, including Microstaurus chiastius, Axopodorhabdus albianus, Corollithion kennedyi, and Lithraphidites acutum lie in chalk just below the glauconitic claystone in Sample 122$763 \mathrm{C}-2 \mathrm{R}-1,78-79 \mathrm{~cm}$. These events are spread out over a 5-m interval in the Western Interior Basin (Bralower, 1988). No Turonian markers were observed in the glauconitic claystone in Section 122-763C-2R-1. This interval is largely barren and those assemblages which do occur are extremely etched.

Although there is no evidence for a break in sedimentation across the Cenomanian-Turonian boundary in either section, sedimentologic and biostratigraphic evidence indicates that this interval is clearly condensed. This boundary interval represents a major transgressive phase (e.g., Haq et al., 1987) preceding one of the highest sea-level highstands of the Phanerozoic era. Three possible explanations exist for the lack of carbonate in horizons of this age on the Exmouth Plateau: 
1. The transgression may have led both to sequestering of carbonate and increased upwelling in shelf environments, and an accentuation of the normal shoaling of the carbonate compensation depth (CCD) along continental margins (e.g., Berger and Winterer, 1974; Arthur et al., 1987). This resulted in poor carbonate preservation, slow sedimentation, erosion and nondeposition in shelf sections such as Sites 762 and 763 .

2. Oceanic community structure changed at this time, precluding calcareous planktonic microfossils in particular environments.

3. Complete dissolution of carbonate took place in the highly corrosive bottom waters associated with the increased fluxes of organic material (e.g., Bralower, 1988).

\section{An Expanded Upper Santonian to Maestrichtian Composite Section}

Our results indicate that combined Holes 761B, 762C, and 763B provide two complete composite upper Santonian to upper Maestrichtian sections. Hole 762C appears to be complete from the Cenomanian through to the Cretaceous/Tertiary boundary. Hole 761B contains an apparently complete and expanded Maestrichtian and a condensed Campanian. Hole 763B appears to have recovered an expanded Coniacian to Campanian sequence.

Although there are some significant differences in assemblages and ranges between Exmouth and Wombat Plateau holes, which will be discussed in the following section, there are numerous events that occur in a consistent order and appear to have biostratigraphic utility (Figs. 2-5; Tables 4 and 5). Almost half of these events have not been used in previous zonations. The following is a short discussion of the relative merits of these potential biostratigraphic markers.

Lithraphidites praequadratus was differentiated from $L$. quadratus morphometrically (Roth, 1978). As these taxa occur consistently in the Maestrichtian, their first occurrences are potentially useful events, although exact measurements need to be made to differentiate them from one another and from L. carniolensis. The first and last occurrences of Petrarhabdus copulatus are useful events in the upper Campanian and lower Maestrichtian, respectively. This species is extremely distinctive (Pl. 2); however, its stratigraphic distribution is often patchy (e.g., Table 2 , back pocket), and its distribution appears to have been limited to temperate and high-latitude sites (e.g., Wise, 1983). The last occurrence of Broinsonia parca is a pronounced event in the lower Maestrichtian. This species is taxonomically distinctive and occurs consistently in the sections observed. The last occurrence of Eiffellithus eximius is a little less reliable, as the abundance of this species tends to decrease toward the top of its range. The last occurrence of Quadrum trifidum is a moderately useful event. Although this species is extremely distinctive, it is quite rare in most of the samples observed. The first occurrence of Arkhangelskiella cymbiformis has biostratigraphic potential in well-preserved material; however, in the material observed here, common overgrowth has rendered this taxon difficult to distinguish consistently from Broinsonia enormis (see Appendix for full discussion). Several events of Polycyclolithaceae species, the first and last occurrences of Lithastrinus grillii, the first occurrence of Eprolithus moratus, and the first occurrence of Eprolithus floralis help subdivide the Santonian to lower Campanian interval. These taxa are distinctive and occur consistently in the sections studied. The first occurrence of Parhabdolithus regularis in the upper Santonian is another useful event, as this species is both distinctive and a common element of the investigated assemblages.
The combination of events from these three sections and other DSDP/ODP sequences will allow development of an Upper Cretaceous biozonation for the eastern part of Tethys.

\section{Paleobiogeography of Upper Cretaceous Exmouth Plateau} Assemblages and Diachroneity of Nannofossil Events

As stated earlier, the major focus of this investigation is biostratigraphy and not paleobiogeography. No detailed quantitative assemblage studies have been conducted and therefore the paleobiogeographic significance of nannofossil assemblages cannot be interpreted rigorously. However, certain rudimentary paleobiogeographic observations can be made based on obvious differences in Campanian-Maestrichtian assemblages between Hole 761B and Holes 762C and 763B, and on the differing stratigraphic ranges of key marker taxa between these locations.

The order of important Upper Cretaceous biohorizons is different between Holes 761B and 762C and 763B (Table 4). Diachroneity between sites can be established in two major ways. In the first, the relative order of events can be compared, and significant disparities may be attributed to diachroneity. Care must be taken to analyze the relative reliability of events in the different sites and to take into account the effect of incomplete recovery. A second method involves the correlation of events with the geomagnetic polarity time scale. In this case, care must be taken to avoid circular reasoning, as it is often the events themselves which help identify magnetic polarity zones. The relative order of Santonian-Maestrichtian calcareous nannofossil events in Holes 761B and 762C are compared in Figure 6. We do not include Hole 763B in this analysis, as the order of events in this hole is similar to Hole $762 \mathrm{C}$.

Hole 761B contains a thinner Upper Cretaceous section than Hole $762 \mathrm{C}$ with poorer recovery (Fig. 6). This problem aside, it is clear from the order of events and correlation with magnetostratigraphy that there are biohorizons that are timetransgressive between the sites. These events include the first occurrences of Nephrolithus frequens and Lithraphidites praequadratus and the last occurrence of Lithastrinus grillii.

The first occurrence of Lithraphidites praequadratus appears to lie relatively lower in Hole 761B than in Hole 762C, correlating with polarity zone $31 \mathrm{R}$ in the former hole and probably with zone $31 \mathrm{~N}$ in the latter. The relative order of this event is inconsistent with other events including the last occurrences of Petrarhabdus copulatus, Reinhardtites levis, and Tranolithus orionatus (Fig. 6). The last occurrence of Lithastrinus grillii lies relatively higher in Hole 761B compared to Hole $762 \mathrm{C}$ with respect to the first occurrences of Quadrum trifidum, $P$. copulatus, and $Q$. gothicum.

The most clearly diachronous event is the first occurrence of Nephrolithus frequens. This biohorizon is clearly out of order with respect to four other nannofossil events. Although in some doubt (see next section for discussion), the first occurrence of $N$. frequens appears to lie in polarity zone $30 \mathrm{~N}$ in Hole $761 \mathrm{~B}$ and $31 \mathrm{~N}$ in Hole $762 \mathrm{C}$ (Fig. 6). The apparent diachroneity of Nephrolithus frequens has been observed before in comparisons of late Maestrichtian biostratigraphies of high- and low-latitude sites (Worsley, 1974; Wise, 1988; Pospichal and Wise, 1990). Nephrolithus frequens has a predominantly high-latitude distribution, whereas Micula murus is more common in material from low-latitude sequences. Thus, the fact that the first occurrence of $N$. frequens lies relatively lower in the southern Site 762 than in Site 761 is consistent with previous observations; however, the magnitude of this diachroneity is surprising considering that the two sites were only separated by $3^{\circ}$ of latitude. This interesting result indicates either that there must have been an extremely 


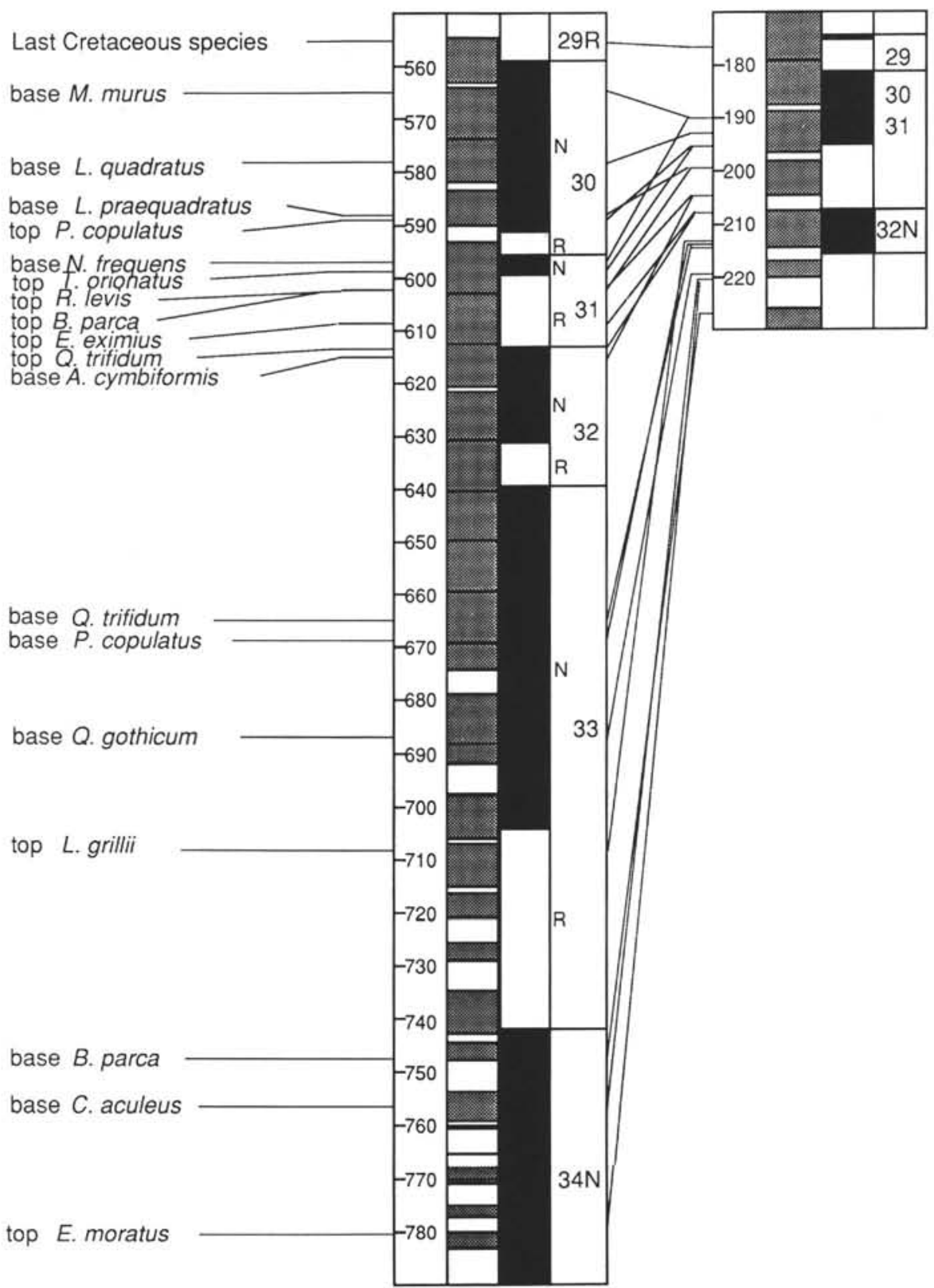

Figure 6. Correlation of Upper Cretaceous nannofossil biohorizons from Hole $762 \mathrm{C}$ to Hole $761 \mathrm{~B}$. Shown on left of each block diagram is depth in meters below seafloor. On right of each block diagram is illustrated magnetostratigraphy from Galbrun (this volume, chapter 42). Diagonal lines between block diagrams illustrate correlation of events between the two holes. The diagram illustrates the differing order of events in the two holes and apparent diachroneity of numerous biohorizons. See text for full discussion.

marked thermal gradient over the Exmouth Plateau region at this time, or else that some other ecological variable as well as temperature controlled the distribution of these taxa.

Several events coincide at a particular horizon at one site but are separated at the other (Fig. 6). An example is the first occurrences of Broinsonia parca and Parhabdolithus regularis. The co-occurrence of these events at Site $762 \mathrm{C}$ could indicate an unconformity; alternatively, these events may be separated with a more detailed investigation. With these exceptions the order of events between Holes 761B and 762C is nearly comparable (Fig. 6). Minor differences can be expected from the generally better preservation of assemblages in Hole 761B. Moreover, Hole 761B is more condensed and contains poorer recovery than Hole $762 \mathrm{C}$ and this could have affected biostratigraphic accuracy.

There are some basic differences in the composition of assemblages in the Santonian-Maestrichtian sections of the two sets of holes, indicating that paleobiogeographic controls may be responsible for the diachroneity of events. Species that are less abundant in Hole 761B than Holes 762C/763B 
include Broinsonia parca, B. signata, Kamptnerius magnificus, Lithastrinus grillii, Eprolithus floralis, E. moratus, and Reinhardtites levis. In addition Hole 761B lacks the dramatic fluctuation in abundances of Micula staurophora and Lucianorhabdus cayeuxii which are present in the other sites. Most of these species have been shown to exhibit abundance peaks at high latitudes (Roth and Bowdler, 1981; Thierstein, 1981; Roth and Krumbach, 1986). It is not surprising that given the significant compositional differences, the ranges vary between the sets of sites. What is interesting, however, is that these compositional differences indicate significant paleobiogeographic differences between two sets of sites which are only separated by a few degrees of latitude. We speculate that there must have been a strong thermal gradient in the SantonianMaestrichtian interval over the Exmouth Plateau, but also that the higher latitude species may have preferred the more marginal setting of the central Exmouth Plateau sites.

\section{Correlation of Upper Cretaceous Calcareous Nannofossil Biostratigraphy with Planktonic Foraminifer Biostratigraphy and Magnetostratigraphy}

There have been several recent investigations of the correlation between calcareous nannofossil biostratigraphy and the geomagnetic polarity time scale (e.g., Tauxe et al., 1983; Manivit and Feinberg, 1984; Stradner and Steinmetz, 1984; Monechi and Thierstein, 1985). These correlations can be made in sedimentary land and deep-sea sections and at sediment/basalt contacts. The magnetostratigraphic results of Galbrun (this volume, chapter 42) from Holes 761B and 762C, combined with our biostratigraphic data, allow a comparison with these previous investigations. The correlation of magnetostratigraphy and the geomagnetic polarity time scale derived from seafloor magnetic anomalies (e.g., Heirtzler et al., 1968) is not clear-cut for either hole (Galbrun, this volume, chapter 42 ), as there are too many reversals in both holes, and several unrecovered intervals of unknown polarity. However, most of the major biomagnetostratigraphic results of this investigation agree with those of previous studies. These correlations include: first occurrence of Micula murus and polarity zone $30 \mathrm{~N}$, last occurrence of Quadrum trifidum and polarity zone $32 \mathrm{~N}$, and first occurrences of $Q$. trifidum and $Q$. gothicum and polarity zone $33 \mathrm{~N}$ (Figs. 6 and 7).

There are certain problems, however. The first occurrence of Lithraphidites quadratus lies in polarity zone $31 \mathrm{~N}$ in most sections, including Bottaccione (Monechi and Thierstein, 1985), DSDP Site 524 (Tauxe et al., 1983), DSDP Sites 525 and 527 (Manivit and Feinberg, 1984), and Hole 761B, but in polarity zone $30 \mathrm{~N}$ in Holes $530 \mathrm{~A}$ (Stradner and Steinmetz, $1984)$ and $762 C$. This disparity may result from misidentification of polarity zone $31 \mathrm{~N}$ in Hole $762 \mathrm{C}$ (Fig. 6). This polarity zone is separated from zone $30 \mathrm{~N}$ by a short reversed interval that is not recorded in some sections such as Hole 761B. Galbrun (this volume, chapter 42) separated polarity zones $30 \mathrm{~N}$ and $31 \mathrm{~N}$ based on two reversed samples with relatively low inclinations. Thus, there is a possibility that polarity zone $31 \mathrm{~N}$ may be included in zone $30 \mathrm{~N}$. The last occurrence of Eiffellithus eximius lies within polarity zone $33 \mathrm{~N}$ at Bottaccione (Monechi and Thierstein, 1985) and Hole 530A (Stradner and Steinmetz, 1984), but in polarity zone 31R at Hole $762 \mathrm{C}$ and at the boundary between polarity zones $31 \mathrm{R}$ and $32 \mathrm{~N}$ in Hole 761B. This considerable difference is difficult to explain. Another event which has a variable magnetostratigraphic correlation is the first occurrence of Nephrolithus frequens. This event lies within polarity zone $30 \mathrm{~N}$ at DSDP Sites 524 (Tauxe et al., 1983) and 525 (Manivit and Feinberg, 1984) and Hole 761B, polarity zone $31 \mathrm{~N}$ at DSDP Sites 384 and 387 (Okada and Thierstein, 1979) and Hole 762C, and polarity zone 31R in ODP Site 690 (Pospichal and Wise, 1990). The time-transgressive first occurrence of $N$. frequens in Leg 122 sites is consistent with the equatorward migration of this species as proposed by Pospichal and Wise (1990).

Other events show smaller disparities. The last occurrence of Broinsonia parca lies in polarity zone $31 \mathrm{R}$ in Holes 761B and $762 \mathrm{C}$, and in polarity zone $32 \mathrm{~N}$ at Bottaccione. The last occurrence of Reinhardtites levis lies in polarity zone $31 \mathrm{R}$ at DSDP Site 525 (Manivit and Feinberg, 1984), ODP Site 690 (Pospichal and Wise, 1990), and Holes 761B and 762C, but in polarity zone $31 \mathrm{~N}$ at DSDP Site 384 (last occurrence of $Z$. anthophorus, Okada and Thierstein, 1979) and in polarity zone $32 \mathrm{~N}$ in DSDP Hole 530A (Stradner and Steinmetz, 1984). The consensus of results points to a correlation between the last occurrence of $R$. levis and polarity zone $31 \mathrm{R}$. The first occurrence of $B$. parca lies within polarity zone $33 \mathrm{R}$ in the Bottaccione section (Monechi and Thierstein, 1985) and Hole 530A (Stradner and Steinmetz, 1984), but below this at the top of polarity zone $34 \mathrm{~N}$ (the long normal) in Hole $762 \mathrm{C}$. This slight disparity could be a result of the extremely expanded section in Hole $762 \mathrm{C}$ and the occurrence of early, very small forms of $B$. parca (see Appendix). The correlation of calcareous nannofossil events with the geomagnetic polarity time scale as suggested by data from Holes $761 \mathrm{~B}$ and $762 \mathrm{C}$ is shown in Figure 7.

Correlation between Albian-Maestrichtian calcareous nannofossil and planktonic foraminifer biostratigraphies (from Wonders, this volume) is also illustrated in Figure 7. These correlations are derived from Hole $762 \mathrm{C}$ for the TuronianMaestrichtian interval and from Hole 763B for the AlbianCenomanian interval, although the results from the other holes in general agree with those presented. We base the correlations on the above intervals in these two holes because they represent the most continuous, expanded sections. In the majority of cases, the chronostratigraphic boundaries as indicated by planktonic foraminifer agree surprisingly well with those based on calcareous nannofossils.

\section{CONCLUSIONS}

1. Three sites from Leg 122, Site 761 on the Wombat Plateau and Sites 762 and 763 on the Exmouth Plateau, provide a composite Cretaceous section ranging in age from Berriasian to Maestrichtian. Together, these sites provide an apparently complete, expanded Aptian-Maestrichtian record. Consistently occurring and predominantly moderately wellpreserved nannofossil assemblages allow reasonably high biostratigraphic resolution.

2. Our data indicate that traditional middle, and particularly Upper Cretaceous nannofossil biozonations, were not entirely applicable in this region. Detailed analysis of the similarities and differences in the relative ranges of key Cretaceous nannofossil markers in the eastern Indian Ocean and in stratotype, parastratotype and other sections from Europe and North Africa is possible. We have determined which previously used markers are applicable and which additional markers have biostratigraphic utility in this region.

3. Nannofossil biostratigraphic investigation of these sections has led to the following highlights: (1) age calibration of portions of the Neocomian Barrow Delta sequence, (2) an expanded Albian-Cenomanian section with well-preserved temperate nannofloras allowing calibration of high- and lowlatitude zonation schemes, (3) two Cenomanian-Turonian boundary sections, (4) an expanded upper Santonian-Maestrichtian section cored at two sites, showing unusual assemblage differences probably as a result of a strong thermal gradient, (5) an almost complete Cretaceous/Tertiary bound- 
STAGE $\quad$ EVENT

NANNOFOSSIL ZONE FORAMINIFERZONE SISSINGH ROTH

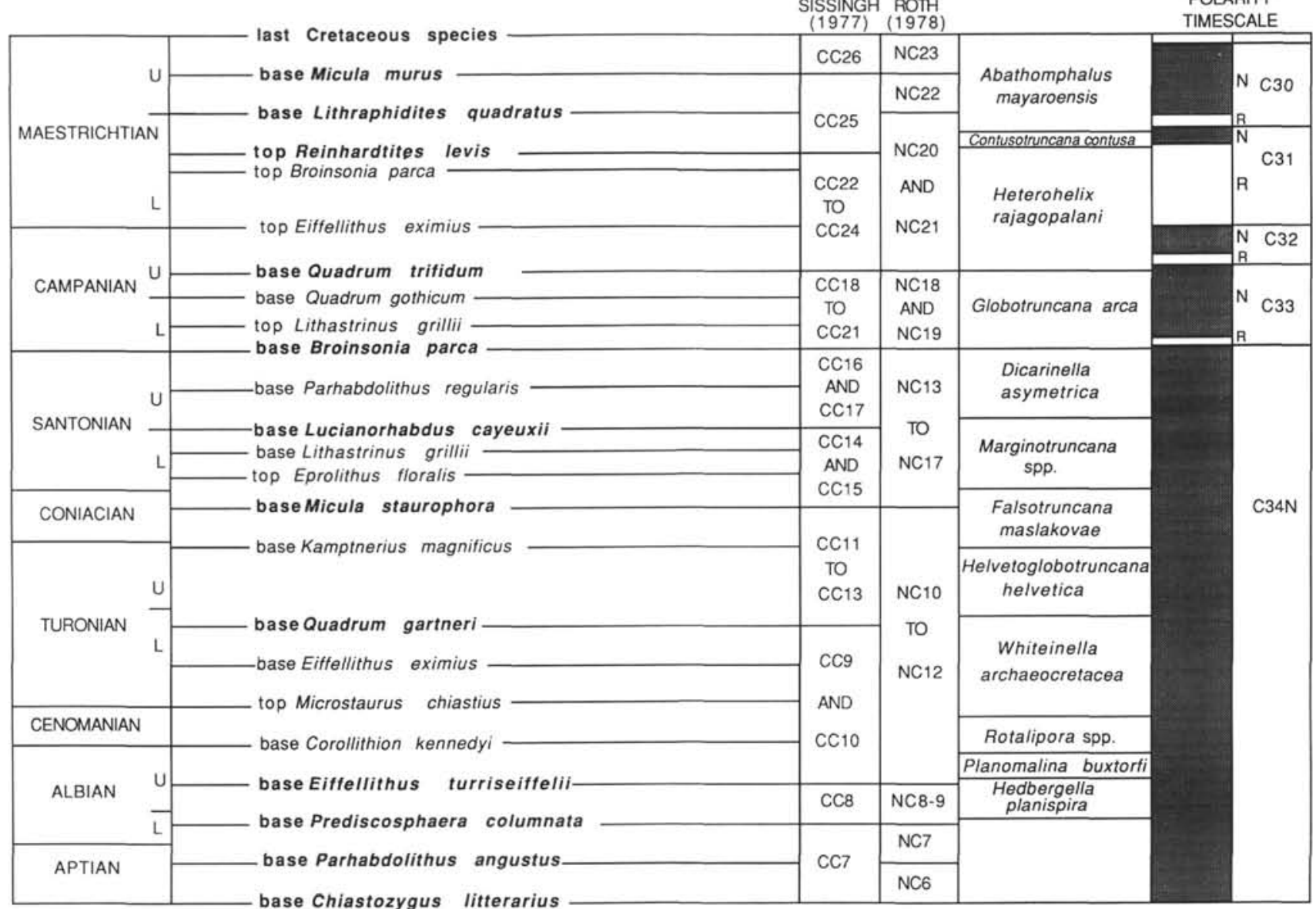

Figure 7. Correlation of Albian-Maestrichtian calcareous nannofossil biostratigraphy with foraminifer biostratigraphy and magnetostratigraphy based on results from Holes 763B (Albian-Cenomanian) and 762C (Turonian-Maestrichtian). Gray pattern indicates recovery. See text for full discussion.

ary, and (6) correlation of Upper Cretaceous calcareous nannofossil biostratigraphy with magnetostratigraphy and foraminifer biostratigraphy.

\section{ACKNOWLEDGMENTS}

The authors acknowledge discussions with R. Boyd, W. Brenner, B. Clement, J. Crux, B. Galbrun, B. Haq, J. Pospichal, D. Watkins, S. Wise, and A. Wonders. We are grateful to B. Haq, J. Pospichal, and D. Watkins for critical reviews. We thank N. Chasens and N. Romer (University of Miami) for assistance with the SEM and J. Arfstrom, C. Botelho, and L. Sierra for darkroom and laboratory assistance. Research funded by USSAC.

\section{REFERENCES}

Arthur, M. A., Schlanger, S. O., and Jenkyns, H. C., 1987. The Cenomanian-Turonian oceanic anoxic event, II. Palaeoceanographic controls on organic-matter production and preservation. In Brooks, J., and Fleet, A. J. (Eds.), Marine Petroleum Source Rocks. Geol. Soc. Spec. Publ. London, 26:401-420.

Berger, W. H., and Winterer, E. L., 1974. Plate stratigraphy and the fluctuating carbonate line. In Hsü, K. J., and Jenkyns, H. C. (Eds.), Pelagic Sediments on Land and Under the Sea: Spec. Publ. Int. Assoc. Sedimentol., 1:11-48.

Bralower, T. J., 1988. Calcareous nannofossil biostratigraphy and assemblages of the Cenomanian-Turonian boundary interval: im- plications for the origin and timing of oceanic anoxia. Paleoceanography, 3:275-316.

Bralower, T. J., Monechi, S., and Thierstein, H. R., 1989. Calcareous nannofossil zonation of the Jurassic-Cretaceous boundary interval and correlation with the geomagnetic polarity timescale. Mar. Micropaleontol., 11:253-335.

Bukry, D., 1969. Upper Cretaceous coccoliths from Texas and Europe. Univ. Kansas Paleontol. Contrib., 51:1-79.

Cepek, P., and Hay, W. W., 1969. Calcareous nannoplankton and biostratigraphic subdivision of the Upper Cretaceous. Trans. Gulf Coast Assoc. Geol. Soc., 19:323-336.

Covington, J. M., and Wise, S. W., Jr., 1987. Calcareous nannofossil biostratigraphy of a Lower Cretaceous deep-sea fan: Deep Sea Drilling Project Leg 93 Site 603, lower continental rise off Cape Hatteras. In van Hinte, J. E., Wise, S. W., Jr., et al., Init. Repts. DSDP, 93: Washington (U.S. Govt. Printing Office), 617-660.

Crux, J. A., 1982. Upper Cretaceous (Cenomanian to Campanian) calcareous nannofossils. In Lord, A. R. (Ed.), A Stratigraphical Index of Calcareous Nannofossils: Chichester (Ellis Horwood), 81-135.

1989. Biostratigraphy and paleogeographical applications of Lower Cretaceous nannofossils from north-western Europe. In Crux, J. A., and van Heck, S. E. (Eds.) Nannofossils and Their Applications: Chichester (Ellis Horwood), 143-211.

Gartner, S., Jr., 1968. Coccoliths and related calcareous nannofossils from Upper Cretaceous deposits of Texas and Arkansas. Univ. Kansas Paleontol. Contrib., No. 48. 
Haq, B. U., Hardenbol, J., and Vail, P. R., 1987. Chronology of fluctuating sea levels since the Triassic. Science, 235:1156-1167.

Haq, B. U., von Rad, U., O'Connell, S., et al., 1990. Proc. ODP, Init. Repts., 122: College Station, TX (Ocean Drilling Program).

Heirtzler, J. R., Dickson, G. O., Herron, E. M., Pitman, W. C., and Le Pichon, X., 1968. Marine magnetic anomalies, geomagnetic field reversals, and motions of the ocean floor and continents. $J$. Geophys. Res., 23:2119-2136.

Hill, M. E., and Bralower, T. J., 1987. Early evolution, stratigraphy and taxonomy of Eiffellithus eximius and related species. Abh. Geol. Bundesanst Austria, 39:89-97.

Jakubowski, M., 1987. A proposed Lower Cretaceous calcareous nannofossil zonation scheme for the Moray Firth area of the North Sea. Abh. Geol. Bundesanst. Austria, 39:99-119.

Leckie, R. M., 1985. Foraminifera of the Cenomanian-Turonian boundary interval, Greenhorn Formation, Rock Canyon anticline, Pueblo, Colorado. In Pratt, L. M., Kauffman, E. G., and Zelt, F. B. (Eds.), Fine-grained Deposits and Biofacies of the Cretaceous Western Interior Seaway: Evidence of Cyclic Sedimentary Processes. Soc. Econ. Paleontol. Mineral., Field Trip Guidebook, $4: 139-150$.

Manivit, H., and Feinberg, H., 1984. Correlation of magnetostratigraphy and nannofossil biostratigraphy in Upper Cretaceous and lower Paleocene sediments of the Walvis Ridge area. In Moore, T. C. Jr., Rabinowitz, P. D., et al., Init. Repts. DSDP, 74: Washington (U.S. Govt. Printing Office), 469-474.

Manivit, H., Perch-Nielsen, K., Prins, B., and Verbeek, J. W., 1977. Mid Cretaceous calcareous nannofossil biostratigraphy. Proc. $K$. Ned. Akad. Wet., Ser. B: Palaeontol., Geol., Phys., Chem., 80:169-191.

Martini, E., 1976. Cretaceous to Recent calcareous nannoplankton from the Central Pacific Ocean (DSDP Leg 33). In Schlanger, S. O., Jackson, E. D., et al., Init. Repts. DSDP, 33: Washington (U.S. Govt. Printing Office), 383-423.

Monechi, S., and Thierstein, H. R., 1985. Late Cretaceous-Eocene nannofossil and magnetostratigraphic correlations near Gubbio, Italy. Mar. Micropaleontol., 9:419-440.

Moshkovitz, S., and Eshet, Y., 1989. Inter-relative aspects of nannofossil and palynomorph biostratigraphy and paleoecology at the $\mathrm{K} / \mathrm{T}$ boundary, Hor Ha'ar section, southern, lsrael. INA Newsl., 11:80-81.

Müller, C., 1985. Biostratigraphic and paleoenvironmental interpretation of the Goban Spur Region based on a study of calcareous nannoplankton. In de Graciansky, P. C., Poag, C. W., et al., Init. Repts. DSDP, 80: Washington (U.S. Govt. Printing Office), 573-600.

Mutterlose, J., in press. Lower Cretaceous nannofossil biostratigraphy of ODP Leg 123 off Northwest Australia, E. Indian Ocean. In Gradstein, F. M., Ludden, J. N., et al., Proc. ODP, Sci. Results, 123: College Station, TX (Ocean Drilling Program).

Okada, H., and Thierstein, H. R., 1979. Calcareous nannoplanktonLeg 43, Deep Sea Drilling Project, In Tucholke, B. E., Vogt, P. R., et al., Init. Repts. DSDP, 43: Washington (U.S. Govt. Printing Office), 507-573.

Perch-Nielsen, K., 1977. Albian to Pleistocene calcareous nannofossils from the western South Atlantic. In Perch-Nielsen, K., Supko, P. R., et al., Init. Repts. DSDP, 39: Washington (U.S. Govt. Printing Office), 699-823.

1979. Calcareous nannofossils from the Cretaceous between the North Sea and the Mediterranean. In Wiedmann, J. (Ed.), Aspekte der Kreide Europeas. Int. Union Geol. Sci. Ser. A, 6:223-272.

1985. Mesozoic calcareous nannofossils. In Bolli, H. Saunders, J. B., and Perch-Nielsen, K. (Eds.), Plankton Stratigraphy: Cambridge (Cambridge Univ. Press), 329-426.

Pospichal, J. J., and Wise, S. W., Jr., 1990. Maestrichtian calcareous nannofossil biostratigraphy of Maud Rise, ODP Leg 113 Sites 689 and 690 , Weddell Sea. In Barker, P. R., Kennett, J. P., et al., Proc. ODP, Sci. Results, 113: College Station TX (Ocean Drilling Program), 465-487.

Roth, P. H., 1978. Cretaceous nannoplankton biostratigraphy and oceanography of the northwestern Atlantic Ocean. In Benson, W. E., Sheridan, R. E., et al., Init. Repts. DSDP, 44: Washington (U.S. Govt. Printing Office), 731-760.
1983. Jurassic and Lower Cretaceous calcareous nannofossils in the western North Atlantic (Site 534): biostratigraphy, preservation and some observations on biogeography and paleoceanography. In Sheridan, R. E., Gradstein, F. M., et al., Init. Repts. DSDP, 76: Washington (U.S. Govt. Printing Office), 587621.

Roth, P. H., and Bowdler, J., 1981. Middle Cretaceous calcareous nannoplankton biogeography and oceanography of the Atlantic Ocean. In Warme, J. E., Douglas, R. G., and Winterer, E. L. (Eds.), The Deep Sea Drilling Project: a Decade of Progress. Spec. Publ. Soc. Econ. Paleontol. Mineral., 32:517-546.

Roth, P. H., and Krumbach, K. R., 1986. Middle Cretaceous calcareous nannofossil biogeography and preservation in the Atlantic and Indian Oceans: implications for paleoceanography. Mar. Micropaleont. 10:235-266.

Schlanger, S. O., Arthur, M. A., Jenkyns, H. C., and Scholle, P. A., 1987. The Cenomanian-Turonian Oceanic Anoxic Event, I. Stratigraphy and distribution of organic carbon-rich beds and the marine $\delta^{13} \mathrm{C}$ excursion. In Brooks, J., and Fleet, A. J. Marine Petroleum Source Rocks. Geol. Soc. Spec. Publ. London, 26:371-399.

Schlanger, S. O., and Jenkyns, H. C., 1976. Cretaceous oceanic anoxic events: causes and consequences. Geol. Mijnbouw, 55:179-184.

Sissingh, W., 1977. Biostratigraphy of Cretaceous calcareous nannoplankton. Geol. Mijnbouw, 56:37-50.

Stradner, H., and Steinmetz, J., 1984. Cretaceous calcareous nannofossils from the Angola Basin, Deep Sea Drilling Project Site 530. In Hay, W. W., Sibuet, J.-C., et al., Init. Repts. DSDP, 75: Washington (U.S. Govt. Printing Office), 565-649.

Tauxe, L., Tucker, P., Petersen, N. P., and LaBrecque, J. L., 1983. The magnetostratigraphy of Leg 73 sediments. Palaeogeogr., Palaeoclimatol., Palaeoecol., 42:65-90.

Thierstein, H. R., 1971. Tentative Lower Cretaceous nannoplankton zonation. Eclogae Geol. Helv., 64:458-488.

, 1973. Lower Cretaceous calcareous nannoplankton biostratigraphy. Abh. Geol. Bundesanst. Austria, 29:1-52. 1974. Calcareous nannoplankton, Leg 26, Deep Sea Drilling Project. In Davies, T. A., Luyendyk, B. P., et al., Init. Repts. DSDP, 26: Washington (U.S. Govt. Printing Office), 619-667. 1976. Mesozoic calcareous nannoplankton biostratigraphy of marine sediments. Mar. Micropaleontol., 1:325-362. , 1977. Mesozoic calcareous nannofossils from the Indian Ocean, DSDP Legs 22 to 27. In Heirtzler, J. R., Bolli, H. M., Davies, T. A., Saunders, J. B., and Sclater, J. G. (Eds.), Indian Ocean Geology and Biostratigraphy. Am. Geophys. Union, 339351.

1980. Selective dissolution of late Cretaceous and earliest Tertiary calcareous nannofossils: experimental evidence. Cretaceous Res., 2:165-176.

1981. Late Cretaceous nannoplankton and the change at the Cretaceous-Tertiary boundary. In Warme, J. E., Douglas, R. G., and Winterer, E. L. (Eds.), The Deep Sea Drilling Project: A Decade of Progress: Spec. Publ. Soc. Econ. Paleontol. Mineral., 32:355-394.

Thierstein, H. R., Franz, H. E., and Roth, P. H., 1972. Scanning electron and light microscopy of the same small object. Micropaleontology, 17:501-502.

Verbeek, J. W., 1977. Calcareous nannoplankton biostratigraphy of middle and upper Cretaceous deposits in Tunisia, southern Spain and France. Utrecht Micropaleontol. Bull., 16:1-157.

Wise, S. W., Jr., 1983. Mesozoic and Cenozoic calcareous nannofossils recovered by Deep Sea Drilling Project Leg 71 in the Falkland Plateau region, Southwest Atlantic Ocean. In Ludwig, W. J., Krasheninnikov, V. A., et al., Init. Repts. DSDP, 71 (Pt. 2): Washington (U.S. Govt. Printing Office), 481-550.

1988. Mesozoic-Cenozoic history of calcareous nannofossils in the region of the Southern Ocean. Palaeogeogr., Palaeoclimatol., Palaeoecol., 67:157-179.

Wise, S. W., Jr., and Wind, F. H., 1977. Mesozoic and Cenozoic calcareous nannofossils recovered by DSDP Leg 36 drilling on the Falkland Plateau, Southwest Atlantic sector of the Southern Ocean. In Barker, P., Dalziel, I.W.D., et al., Init. Repts. DSDP, 36: Washington (U.S. Govt. Printing Office), 269-492. 
Worsley, T. R., 1974. The Cretaceous/Tertiary boundary event in the ocean. In Hay, W. W. (Ed.), Studies in Paleo-oceanography, Soc. Econ. Paleontol. Mineral. Spec. Publ., 20:94-125.

\section{Date of initial receipt: 31 May 1990}

Date of acceptance: 12 February 1991 Ms 122B-169

\section{APPENDIX}

\section{TAXONOMY}

In the following, informal remarks are made concerning the identification of numerous species which have been described in detail elsewhere.

Vagalapilla aachena Bukry, 1969 (Pl. 5, Figs. 33, 34). This species is a common element of Upper Cretaceous nannofloras from Holes $761 \mathrm{~B}$ and $762 \mathrm{C}$. It is differentiated from other members of Vagalapilla based on the irregular arrangement of its cross. Size varies significantly between 5 and $10 \mu \mathrm{m}$. Previously, its range was reported as Coniacian-Campanian (Bukry, 1969; Thierstein, 1974); however, we have observed it from the upper Santonian to the upper Maestrichtian.

Parhabdolithus achlyostaurion Hill, 1976

Corollithion achylosum (Stover, 1966) Thierstein, 1971

Ceratolithoides aculeus (Stradner, 1961) Prins and Sissingh in Sissingh, 1977 (PI. 7, Figs. 26-31).This species has a variable shape, with some specimens (e.g., PI. 7, Figs. 30,31) being considerably more elongate than others. None of the elongate forms observed have the structure of $C$. verbeekii Perch-Nielsen, 1979. This species appears to be part of the stem of another nannofossil; however, no specimens were observed attached.

Corollithion acutum Thierstein in Roth and Thierstein, 1972

Lithraphidites acutum Manivit et al., 1977

Braarudosphaera africana Stradner, 1961

Axopodorhabdus albianus (Black, 1967) Wind and Wise in Wise and Wind, 1977 (PI. 2, Figs. 1, 2).

Hayesites albiensis Manivit, 1971 (PI. 7, Figs. 22, 23).

Chiastozygus amphipons (Bramlette and Martini, 1964) Gartner, 1968 (Pl. 5, Figs. 17, 18). Chiastozygus is a very variable genus in the Upper Cretaceous. Most of the descriptions of the numerous species defined have been made solely on the basis of electron micrographs (Gartner, 1968; Bukry, 1969). It is therefore unclear how to differentiate the numerous taxa in the light microscope. For this reason, in this study we use only three species and differentiate them on the basis of their central crosses. Chiastozygus amphipons has a narrow, slightly off-diagonal cross with straight bars. C. garrisonii has a wider cross with bifurcating tips, often a central process, and is commonly overgrown. $C$. litterarius has a wide, relatively straight cross which is split lengthwise into two segments.

Cretarhabdus angustiforatus (Black, 1971) Bukry, 1973 (PI. 2, Figs. 19, 20).

Parhabdolithus angustus (Stradner, 1963) Stradner et al., 1968 (Pl. 5 , Figs. 29, 30). This species may be elliptical or kidney-shaped. It is differentiated from $P$. splendens based on its length to width ratio, which is greater than 2 . It sometimes possesses a central process.

Reinhardtites anthophorus (Deflandre, 1959) Perch-Nielsen, 1968 (PI. 5, Figs. 21, 22; Pl. 6, 12-14). This species is differentiated from Reinhardtites levis based on the presence of significant openings in the central area aligned with the long axis. In $R$. levis, there may be small openings but these occur diagonally to the central process. Even though this distinction is made, it is felt here that the variation in size, shape, and position of central openings may be a result of progressive overgrowth of specimens. Scanning electron micrographs, Plate 6, Figures 12 and 13, illustrate specimens of $R$. anthophorus with partially overgrown openings; Plate 6 , Figure 14, shows a proximal view of this species with unaltered openings. Therefore, in overgrown specimens it may be difficult to distinguish this species from $R$. levis. In the lower part of the range of this species, other related zygoliths may be confused with $R$. anthophorus. A form has been observed in the Turonian and Coniacian of Hole $762 \mathrm{C}$ which has extremely large openings in the central area, resembling Placozygus sigmoides. Thus, the range of $R$. anthophorus reported here is difficult to compare with the results of other investigations.

Lucianorhabdus arcuatus Forchheimer, 1972

Prediscosphaera arkhangelskyi (Reinhardt, 1965) Perch-Nielsen, 1984 (Pl. 3, Figs. 25, 26). This rare species is restricted to the SantonianMaestrichtian of all three holes. It is distinguished by its relatively large size (usually longer than $8 \mu \mathrm{m}$ ) and relatively oblate shape. The cross is aligned with the major axes as in $P$. spinosa. It is differentiated from the latter species by its thick, bright white, innermost cycle of elements. The innermost cycle is slightly thicker than previously illustrated specimens, but this could easily be a result of overgrowth.

Parhabdolithus asper (Stradner, 1963) Manivit, 1971 (Pl. 5, Figs. 25, 26; PI. 6, Fig. 10).

Watznaueria barnesae (Black, 1959) Perch-Nielsen, 1968

Microrhabdulus belgicus Hay and Towe, 1963

Watznaueria biporta Bukry, 1969

Micrantholithus brevis Jakubowski, 1986 (PI. 8, Figs. 3, 4).

Amphizygus brooksii Bukry, 1969

Lithraphidites carniolensis Deflandre, 1963

Lucianorhabdus cayeuxii Deflandre, 1959 (PI. 8, Figs. 11-14). This holococcolith possesses two straight parallel bars with no curved endings. It is often very overgrown and is unusually common in certain samples from Hole $762 \mathrm{C}$.

Microstaurus chiastius (Worsley, 1971) Bralower, 1989

Markalius circumradiatus (Stover, 1966) Perch-Nielsen, 1968

Prediscosphaera columnata (Stover, 1966) Perch-Nielsen, 1984. This Albian species is round and unusually small, its diameter ranging from 4-6 $\mu \mathrm{m}$. Its descendant, $P$. cretacea, is elliptical in shape and usually larger.

Watznaueria communis Reinhardt, 1964

Vagalapilla compacta Bukry, 1969

Micula concava (Stradner in Martini and Stradner, 1960) Verbeek, 1976. We use similar criteria to Perch-Nielsen (1985) to differentiate this taxon from $M$. staurophora. $M$. concava, rarely observed in our material, has projections extending beyond the sides of the basic cube, whereas $M$. staurophora possesses no projections. As suggested by Roth and Bowdler (1979), this species appears to be a descendant of $M$. staurophora.

Cretarhabdus conicus Bramlette and Martini, 1964 (Pl. 4, Fig. 8). The central area of this species contains more than one row of perforations whereas $C$. surirellus only has one row. $C$. conicus is very variable in size, its length ranging up to $12 \mu \mathrm{m}$ in the Maestrichtian. It often possesses a distinct cross aligned with the major axes.

Biscutum constans (Gorka, 1957) Black, 1959. This taxon is small, usually less than $6 \mu \mathrm{m}$ in length and possesses a small central area.

Petrarhabdus copulatus (Deflandre, 1959) Wind and Wise, in Wise, 1983 (Pl. 2, Figs. 1-17). This species is common in the material studied and provides a useful marker; we therefore provide additional morphological detail. This is a large, round to elliptical coccolith composed of closely appressed proximal and distal shields. Each shield is composed of one cycle of elements. The proximal shield is constructed of 18-22 non-imbricate trapezoid elements which enclose a narrow central area. The central area in this view may contain a tiny petaloid central process. The distal shield is constructed of 17-19 rhombic elements which imbricate in a clockwise fashion. The central area in this view is larger and contains up to 12 prismatic elements which are arranged in a semi-random fashion. This species is extremely diagnostic in the light microscope due to its size, its very low (first order grey) birefringence in cross-polarized light, and a common stem (which we have not observed in the SEM) composed of four blocky, highly birefringent elements. This stem may be so large as to cover the entire coccolith below it. The structure of this species is quite unusual in that the distal shield is so imbricated and the proximal shield is non-imbricated. Based on 9 specimens measured, the length varies between 12 and $15 \mu \mathrm{m}$, and the width between 8 and $12 \mu \mathrm{m}$. The known range of this species is upper Campanian to upper Maestrichtian.

Cretarhabdus coronadventis Reinhardt, 1966 (PI. 3, Figs. 21, 22).

Biscutum coronum Wind and Wise in Wise and Wind, 1977 (Pl. 1, Figs. 21-26). This species is larger than $B$. constans, usually 
greater than $8 \mu \mathrm{m}$ in length, and possesses a much larger central area which is spanned by an ill-defined structure.

Nephrolithus corystus Wind, 1983 (PI. 3, Figs. 13, 14). This species is much more oblate and regular than its descendant, $N$. frequens. It occurs rarely in the middle-upper Maestrichtian of Hole 762C.

Prediscosphaera cretacea (Arkhangelsky, 1912) Gartner, 1968 (Pl. 3, Figs. 27, 28; Pl. 4, Fig. 2). See remarks for $P$. columnata.

Cruciellipsis cuvillieri (Manivit, 1966) Thierstein, 1971

Arkhangelskiella cymbiformis Vekshina, 1959 (Pl. 1, Figs. 1, 2). Differentiating this form from other arkhangelskiellid taxa in the light microscope can prove problematic and there appears to be significant overlap between species. This problem is compounded in overgrown material, including most samples observed in this study, as this leads to the infilling of pores. We use the following criteria to differentiate $A$. cymbiformis from closely related Broinsonia enormis and $B$. furtiva. First, in well-preserved material, pores are visible in A. cymbiformis but not in the other two species. Secondly, A. cymbiformis has a more well-developed cross structure in the central area and less well-developed quadrants. Since pores are not usually visible in the material examined, we combine $A$. cymbiformis and $A$. speciallata.

Microrhabdulus decoratus Deflandre, 1959 (PI. 8, Figs. 17, 18).

Axopodorhabdus decorus (Deflandre, 1954) Wind and Wise in Wise and Wind, 1977. The central area of this species is usually etched out. In identifiable specimens, the tips of the cross bars are left indicating a diagonal orientation.

Micula decussata Vekshina, 1959. We group this species with $M$. staurophora which is the senior synonym.

Cyclagelosphaera deflandrei Manivit, 1966

Axopodorhabdus dietzmannii (Reinhardt, 1965) Wind and Wise in Wise, 1983

Zygodiscus diplogrammus (Deflandre and Fert, 1954) Gartner, 1968. Openings in the central area of this species are sometimes completely overgrown.

Cribrosphaerella ehrenbergii (Arkhangelsky, 1912) Deflandre, 1952 (PI. 3, Figs. 3, 4; Pl. 4, Figs. 5-7). This species is extremely variable in size and shape. We differentiate it from the less common form, C. linea Gartner (1968) based on the ratio of the width of the central area to the width of the shield. In $C$. ehrenbergii, the width of the central area is wider than that of the shield whereas in $C$. linea the central area is narrower. $C$. ehrenbergii is elliptical in shape but it approaches circular in some samples. The length can be as large as $12 \mu \mathrm{m}$.

Zygodiscus elegans (Gartner, 1968) Bukry, 1969. We differentiate this taxon from $Z$. spiralis based on the shape of the central area and the bridge which spans it. In Z. elegans, the central area is wider relative to the width of the coccolith and the bridge is longer. $Z$. spiralis has a much narrower central area and a shorter bridge.

Corollithion ellipticum Bukry, 1969 (PI. 4, Fig. 10).

Microrhabdulus elongatus Stover, 1966

Nannoconus elongatus Brönnimann, 1955

Parhabdolithus embergeri (Noël, 1958) Bralower, 1989 (PI. 6, Fig. 11).

Broinsonia enormis (Shumenko, 1968) Manivit, 1971 (Pl. 1, Figs. 3, 4). The central area of this species is clearly divided into eight separate quadrants. We have combined Broinsonia furtiva Bukry (1969) with $B$. enormis because the features which differentiate them, the presence of pores and a central cross, can only be easily observed in well-preserved material.

Corollithion exiguum Stradner, 1961 (PI. 5, Figs. 3, 4).

Eiffellithus eximius (Stover, 1966) Perch-Nielsen, 1968 (Pl. 5, Figs. 7, 8). Specimens transitional with Eiffellithus turriseiffelii are observed at the top and bottom of its range. We use criteria defined by Verbeek (1977) to differentiate the two taxa. In E. eximius, the angle between the long axis of the cross and the long axis of the coccolith is less than $15^{\circ}$. We differentiate $E$. cf. E. eximius (PI. 5, Figs. 9, 10), which has an Albian range and a more delicate structure (see Hill and Bralower, 1987).

Sollasites falklandensis Filewicz et al. in Wise and Wind, 1977 (PI. 1, Figs. 31, 32).

Percivalia fenestrata (Worsley, 1971) Wise, 1983

Zygodiscus fissus (Grün and Zweili, 1980) Roth, 1983

Eprolithus floralis (Stradner, 1962) Stover, 1966 (Pl. 7, Figs. 19-21).

Scapholithus fossilis Deflandre in Deflandre and Fert, 1954
Nephrolithus frequens Gorka, 1959 (Pl. 3, Figs. 7, 8). This species has a consistent kidney shape; however, a few older specimens were observed which were more nearly elliptical, and these were included in $N$. corystus Wind (1983).

Marthasterites furcatus (Deflandre in Deflandre and Fert, 1954) Deflandre, 1959. This taxon has only been observed in an extremely overgrown state and therefore may not have been reported as commonly as it occurs.

Broinsonia furtiva Bukry, 1969. This species could not be consistently be differentiated from B. enormis in Leg 122 material (see remarks under $B$. enormis).

Pickelhaube furtiva Covington and Wise, 1987

Tranolithus gabalus Stover, 1966

Ethmorhabdus gallicus Noöl, 1965

Cylindralithus gallicus (Stradner, 1963) Bramlette and Martini, 1964

Broinsonia gammation Hill, 1976 (Pl. 1, Figs. 11-14).

Chiastozygus garrisonii Bukry, 1969 (PI. 5, Figs. 15, 16). See remarks underChiastozygus amphipons.

Quadrum gartneri Prins and Perch-Nielsen in Manivit et al., 1977 (Pl. 7, Figs. 7,8). This is a synonym of Tetralithus pyramidus Gardet.

Hemipodorhabdus gorkae (Reinhardt, 1966) Grün and Allemann, 1975

Quadrum gothicum (Deflandre, 1959) Prins and Perch-Nielsen in Manivit et al., 1977 (Pl. 7, Figs. 11-14). We treat this as a synonym of Tetralithus nitidus Martini. Although the latter taxon has narrower elements, overgrowth would give it a similar appearance to $Q$. gothicum. Similarly, it may be difficult to distinguish $Q$. gothicum from an overgrown specimen of Quadrum gartneri. Such overgrowth can lead to extension of the corners of the elements resulting in a cross-shaped form.

Prediscosphaera grandis Perch-Nielsen, 1979 (Pl. 3, Figs. 23, 24). This circular species is differentiated from related taxa based on size, having a diameter greater than $10 \mu \mathrm{m}$, which may reach 15 $\mu \mathrm{m}$. Its first occurrence lies in the upper Santonian in Holes $762 \mathrm{C}$ and $763 \mathrm{~B}$, which is lower than the reported Maestrichtian range of Perch-Nielsen $(1979,1985)$.

Manivitella granulatus (Risatti, 1973)

Umbria granulosa Bralower and Thierstein in Bralower et al., 1989

Lithastrinus grillii Stradner, 1962 (PI. 7, Figs. 15, 16). Most specimens observed have rounded rather than the typical pointy edges probably as a result of heavy overgrowth.

Percivalia hauxtonensis Black, 1973 (Pl. 6, Figs. 1-7). This species was originally described in the SEM by Black (1973) in samples from the Albian Gault Clay. It has previously not been described in the light microscope. We have used the combined SEM/LM technique of Thierstein et al. (1972) to observe the same specimen in both media. We have observed this species in proximal and distal views (PI. 6) which give a rather similar light microscopic appearance. This consists of a zygodiscid rim and a prominent lozenge-shaped knob in the central area. This species appears to be most common at mid-high latitudes and is a useful mid-late Albian marker.

Sollasites hayi (Black, 1973) Perch-Nielsen, 1984

Sollasites horticus (Stradner et al., 1966) Cepek and Hay, 1969

Micrantholithus hoschulzii (Reinhardt, 1966) Thierstein, 1971

Parhabdolithus infinitus (Worsley, 1971) Thierstein, 1972

Assipetra infracretacea (Thierstein, 1972) Roth, 1973

Markalius inversus (Deflandre in Deflandre and Fert, 1954) Bramlette and Martini, 1964 (Pl. 1, Figs. 29, 30).

Rucinolithus irregularis Thierstein in Roth and Thierstein, 1972

Corollithion kennedyi Crux, 1981 (Pl. 5, Figs. 5, 6).

Rotelapillus laffittei Noël, 1956. In samples with moderate etching and overgrowth, the shield of this species can resemble Cylindralithus gallicus.

Diazomatolithus lehmannii (Noël, 1965)

Reinhardtites levis Prins and Sissingh in Sissingh, 1977. See remarks for $R$. anthophorus. Numerous specimens with a Reinhardtites shield are observed in the upper parts of Holes $761 \mathrm{~B}$ and $762 \mathrm{C}$ above the extinction of $R$. levis sensu stricto. The central areas of these specimens are entirely dissolved and they therefore cannot be classified. However, the last occurrence of this species has a similar magnetostratigraphic correlation to other sites and is thus considered as a reliable event. The first occurrence is less reliable as it may be difficult to distinguish this species from $R$. anthopho- 
rus in overgrown samples. However, our investigations indicate that the first occurrence of $R$. levis may lie in the lower Campanian or upper Santonian, somewhat lower than the upper Campanian range widely cited (e.g., Sissingh, 1977).

Cribrosphaerella linea Gartner, 1968. See remarks under Cribrosphaerella ehrenbergii.

Chiastozygus litterarius (Gorka, 1957) Manivit, 1971. See remarks under Chiastozygus amphipons.

Cretarhabdus loriei Gartner, 1968 (PI. 3, Figs. 17, 18).

Sollasites lowei (Bukry, 1969) Roth, 1970

Corollithion madagaskarensis Perch-Nielsen (1973) (PI. 5, Figs. 1, 2),

Kamptnerius magnificus Deflandre, 1959 (PI. 1, Figs. 19, 20).

Octocyclus magnus Black, 1972 (PI. 3, Figs. 9, 10; PI. 4, Fig. 3).

Lucianorhabdus maleformis Reinhardt, 1966 (Pl. 8, Figs. 15, 16). This species has a similar appearance to $L$. cayeuxii, except for significant widening at the base of the bars.

Cyclagelosphaera margerelii Noël, 1965

Vagalapilla matalosa (Stover, 1966) Thierstein, 1973 (PI. 5, Figs. 31, 32).

Conusphaera mexicana Trejo, 1969

Nannoconus minutus Brönnimann, 1955

Eprolithus moratus Stover, 1966 (Pl. 7, Figs. 17, 18). Most specimens observed have rounded edges probably as a result of heavy overgrowth.

Micula murus (Martini, 1961) Bukry, 1973 (PI. 7, Figs. 1, 2). PerchNielsen (1985) described an early form of $M$. murus, $M$. praemurus, with less extended elements. We did not observe such forms; however, transitional forms with $M$. staurophora were observed early in the range of $M$. murus. In these (e.g., Pl. 7, Figs. 3, 4) the elements are arranged as in the former species, but they possess the extensions diagnostic of the latter species. No $M$. prinsii was seen in the latest Maestrichtian.

Gartnerago nanum Thierstein, 1974 (PI. 1, Figs. 17, 18). This species is small, less than $7 \mu \mathrm{m}$ in length, with a distinct cross in the central area.

Gartnerago obliquum (Stradner, 1963) Reinhardt, 1970 (PI. 1, Figs. $15,16)$. This species is differentiated from $G$. striatum based on the number and size of pores in the central area. G. obliquum has two rows of larger pores, whereas $G$. striatum has over six rows of smaller pores (Thierstein, 1974).

Flabellites oblongus (Bukry, 1969) Crux et al., 1982 (Pl. 3, Figs. 9, 10).

Cretarhabdus octofenestratus Bralower, 1989

Vagalapilla octoradiata (Gorka, 1957) Bukry, 1969 (Pl. 5, Figs. 35, 36).

Tranolithus orionatus (Reinhardt, 1966) Perch-Nielsen, 1968 (Pl. 6, Figs. 8,9 ). We use this as a synonym for $T$. exiguus and $T$. phacelosus.

Broinsonia orthocancellata Bukry, 1969

Watznaueria ovata Bukry, 1969

Broinsonia parca subsp. parca (Stradner, 1963) Bukry, 1969 (Pl. 1, Figs. 7, 8). In this subspecies, described by Hattner et al. (1980), the central area is wider than the shield whereas in $B$. parca subsp. constricta, the shield is wider than the central area. We have observed some extremely small (5-6 $\mu$ m length) specimens in the early part of the range of this species.

Broinsonia parca subsp. constricta Hattner et al., 1980 (Pl. 1, Figs. 9, 10).

Manivitella pemmatoidea (Manivit, 1965) Thierstein, 1971

Lithraphidites praequadratus Roth, 1978 (Pl. 4, Fig. 12; Pl. 8, Figs. $7-10)$. We use an identical criterion to the original definition of Roth (1978) to identify this species; it has a length/width ratio of between 3.5 and 5 , whereas $L$. quadratus and $L$. carniolensis have length/ width ratios of less than 3.5 and greater than 5.0 , respectively.
Cribrosphaerella primitiva Thierstein, 1974 (Pl. 3, Figs. 5, 6).

Eiffellithus primus Applegate and Bergen, 1989

Lithraphidites quadratus Bramlette and Martini, 1964 (Pl. 4, Fig. 11; PI. 8, Figs. 5,6 ). See remarks under $L$. praequadratus.

Vagalapilla quadriarcula (Noël, 1965) Roth, 1983

Braarudosphaera regularis Black, 1973

Parhabdolithus regularis (Gartner, 1968) (PI. 5, Figs. 23, 24).

Rhagodiscus reniformis Perch-Nielsen, 1973

Corollithion rhombicum (Stradner and Adamiker, 1966) Bukry, 1969

Discorhabdus rotatorius (Bukry, 1969) Thierstein, 1973

Conusphaera rothii (Thierstein, 1971) Jakubowski, 1987

Crucibiscutum salebrosum (Black, 1971) Jakubowski, 1986 (Pl. 1, Figs. 27, 28).

Cretarhabdus schizobrachiatus (Gartner, 1968) Bukry, 1969

Lithastrinus septenarius Forchheimer, 1972

Placozygus sigmoides (Bramlette and Sullivan, 1961) Romein, 1979

Broinsonia signata (Noël, 1969) Noël, 1970

Corollithion signum Stradner, 1963

Parhabdolithus splendens (Deflandre, 1953) Noël, 1969 (PI. 5, Figs. 27, 28).

Prediscosphaera spinosa (Bramlette and Martini, 1964) Gartner, 1968 (Pl. 3, Figs. 29, 30; Pl. 4, Fig. 1).

Zygodiscus spiralis Bramlette and Martini, 1964 (Pl. 5, Figs. 19, 20), See remarks under Zygodiscus elegans. We differentiate this species from the dominantly Tertiary form Placozygus sigmoides based on its smaller size.

Micula staurophora (Gardet, 1955) Stradner, 1963 (Pl. 7, Figs. 5, 6).

Tegumentum stradneri Thierstein, 1972

Vagalapilla stradneri (Rood et al., 1971) Thierstein, 1973

Gartnerago striatum (Stradner, 1963) Forchheimer, 1972. See remarks under $G$. obliquum. This species is restricted to the Albian in Hole 763B.

Cretarhabdus surirellus (Deflandre, 1954) Reinhardt, 1970. See remarks under $C$. conicus.

Rucinolithus terebrodentarius (Stover, 1966) Applegate et al. in Covington and Wise, 1987

Eiffellithus trabeculatus (Gorka, 1957) Reinhardt and Gorka, 1967 (PI. 5, Figs. 13, 14).

Quadrum trifidum (Stradner in Stradner and Papp, 1961) Prins and Perch-Nielsen in Manivit et al., 1977 (PI. 7, Figs. 9, 10). This species has a variable shape which depends on the amount of overgrowth. The tips of the elements may be highly pointed or slightly rounded.

Eiffellithus turriseiffelii (Deflandre, 1954) Reinhardt, 1965 (Pl. 5, Figs. $11,12)$. See remarks under E. eximius.

Zebrashapka vanhintei Covington and Wise, 1987

Tubodsicus verenae Thierstein, 1973

Neocrepidolithus watkinsii Pospichal and Wise, 1990. Seen in all of the Indian Ocean sites, this species has been observed in the upper Campanian of Hole 762C. More detailed work may help establish its complete range in this region.

Eiffellithus windii Applegate and Bergen, 1989

Broinsonia sp.

Cretarhabdus sp.

Lapideacassis $\mathrm{sp}$.

Neochiastozygus sp.

Pithonella sp.

Podorhabdus sp.

Thoracosphaera sp.

Zebrashapka sp. (Pl. 7, Figs. 24, 25). 

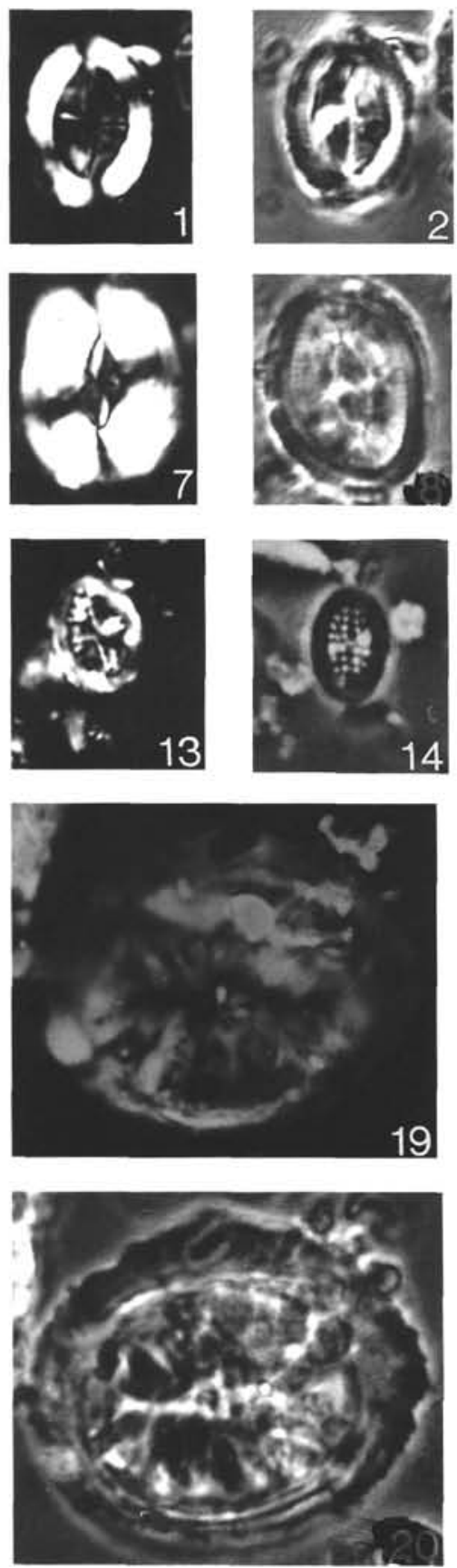
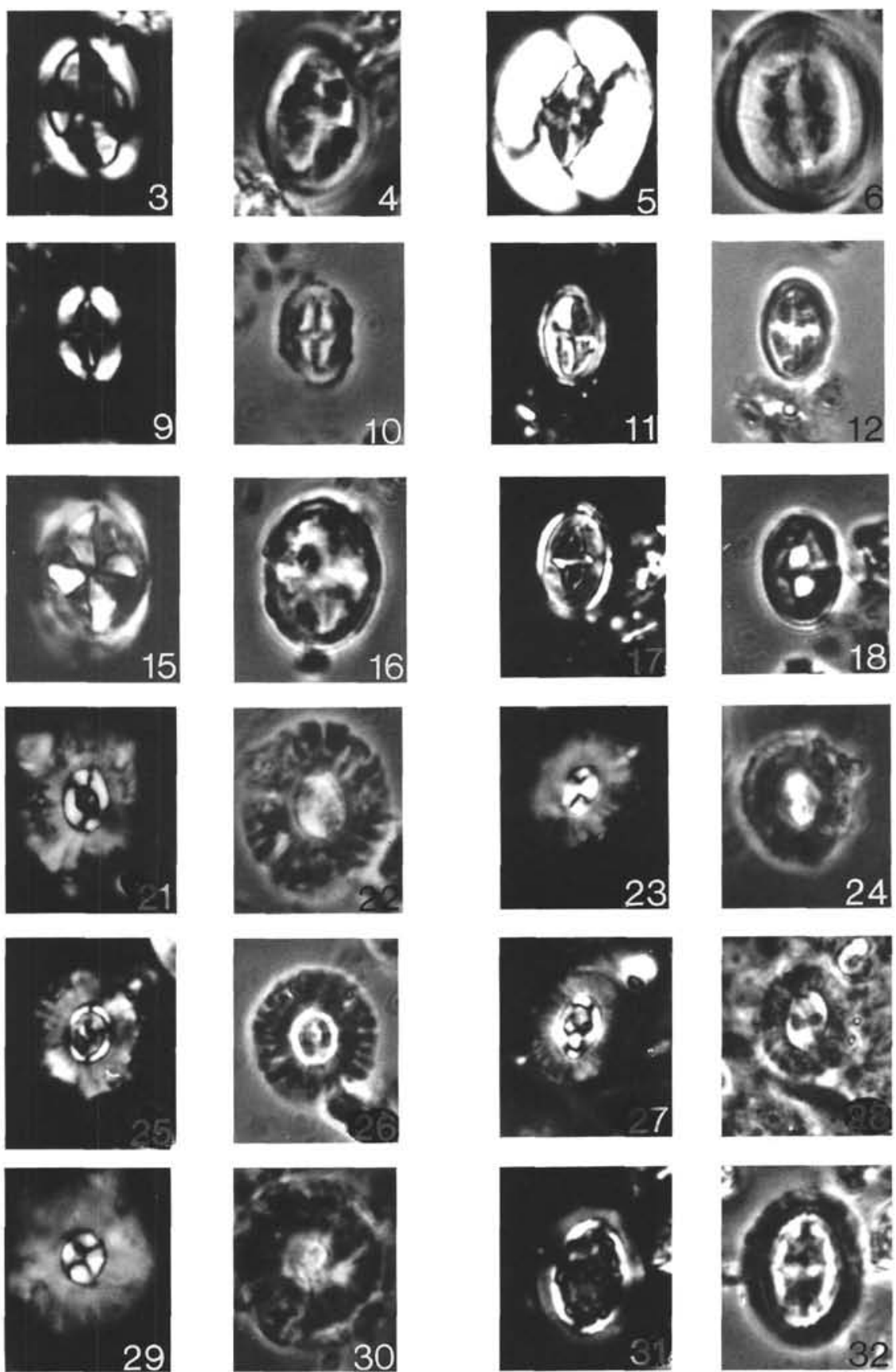
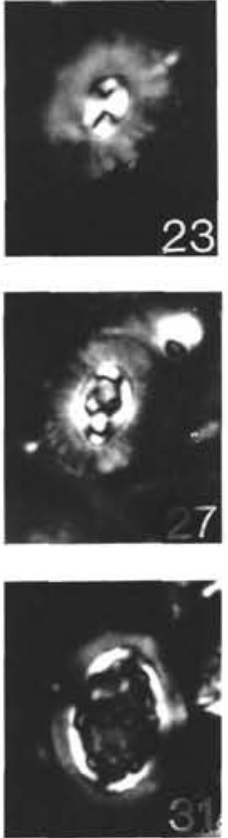
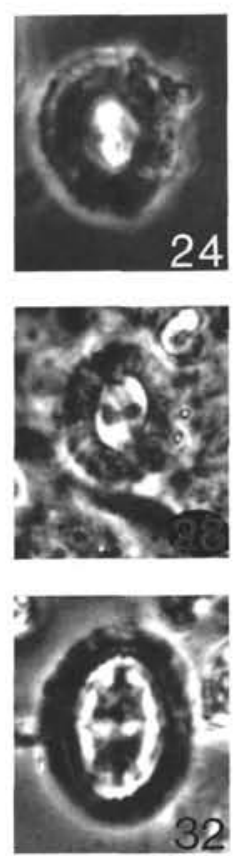

Plate 1. Light micrographs of Arkhangelskiellaceae, Biscutaceae, Ellipsagelosphaeraceae, and Sollasitaceae. 1, 2. Arkhangelskiella cymbiformis. (1) Cross-polarized light, (2) phase contrast; Sample 122-761B-21X-5, 61-62 cm. 3, 4. Broinsonia enormis. (3) Cross-polarized light, (4) phase contrast; Sample 122-761B-25X-1, 41-42 cm. 5, 6. Broinsonia parca subsp. parca. (5) Cross-polarized light, (6) phase contrast; Sample 122-761B-25X-3, 42-43 cm. 7, 8. Broinsonia parca subsp. constricta. (7) Cross-polarized light, (8) phase contrast; Sample 122-761B-25X-1, 41-42 cm. 9, 10. Broinsonia signata. (9) Cross-polarized light, (10) phase contrast; Sample 122-763B-10X-6, 30-32 cm. 11-14. Broinsonia gammation. $(11,13)$ Cross-polarized light, $(12,14)$ phase contrast; $(11,12)$ Sample $122-763 \mathrm{~B}-32 \mathrm{X}-6,30-31 \mathrm{~cm} ;(13,14)$ Sample 122-763B-26X-3, 29-31 cm. 15, 16. Gartnerago obliquum. (15) Cross-polarized light, (16) phase contrast; Sample 122-762C-51X-2, $30-32 \mathrm{~cm} .17$, 18. Gartnerago nanum. (17) Cross-polarized light, (18) phase contrast; Sample 122-763B-24X-4, 30-31 cm. 19, 20. Kamptnerius magnificus. (19) Cross-polarized light, (20) phase contrast; Sample 122-763B-16X-6, 30-32 cm. 21-26. Biscutum coronum. (21, 23, 25) Cross-polarized light, $(22,24,26)$ phase contrast; Sample 122-763B-9X-5, 30-32 cm. 27, 28. Crucibiscutum salebrosum. (27) Cross-polarized light, (28) phase contrast; Sample 122-763C-21R-6, 29-32 cm. 29, 30. Markalius inversus. (29) Cross-polarized light, (30) phase contrast; Sample 122-761B-22X-3, 40-41 cm. 31, 32. Sollasites falklandensis. (31) Cross-polarized light, (32) phase contrast; Sample 122-763B-36X-2, $30-31 \mathrm{~cm}$. All magnifications $2000 \times$. All phase contrast illustrations are of same specimen as previous cross-polarized plate. 

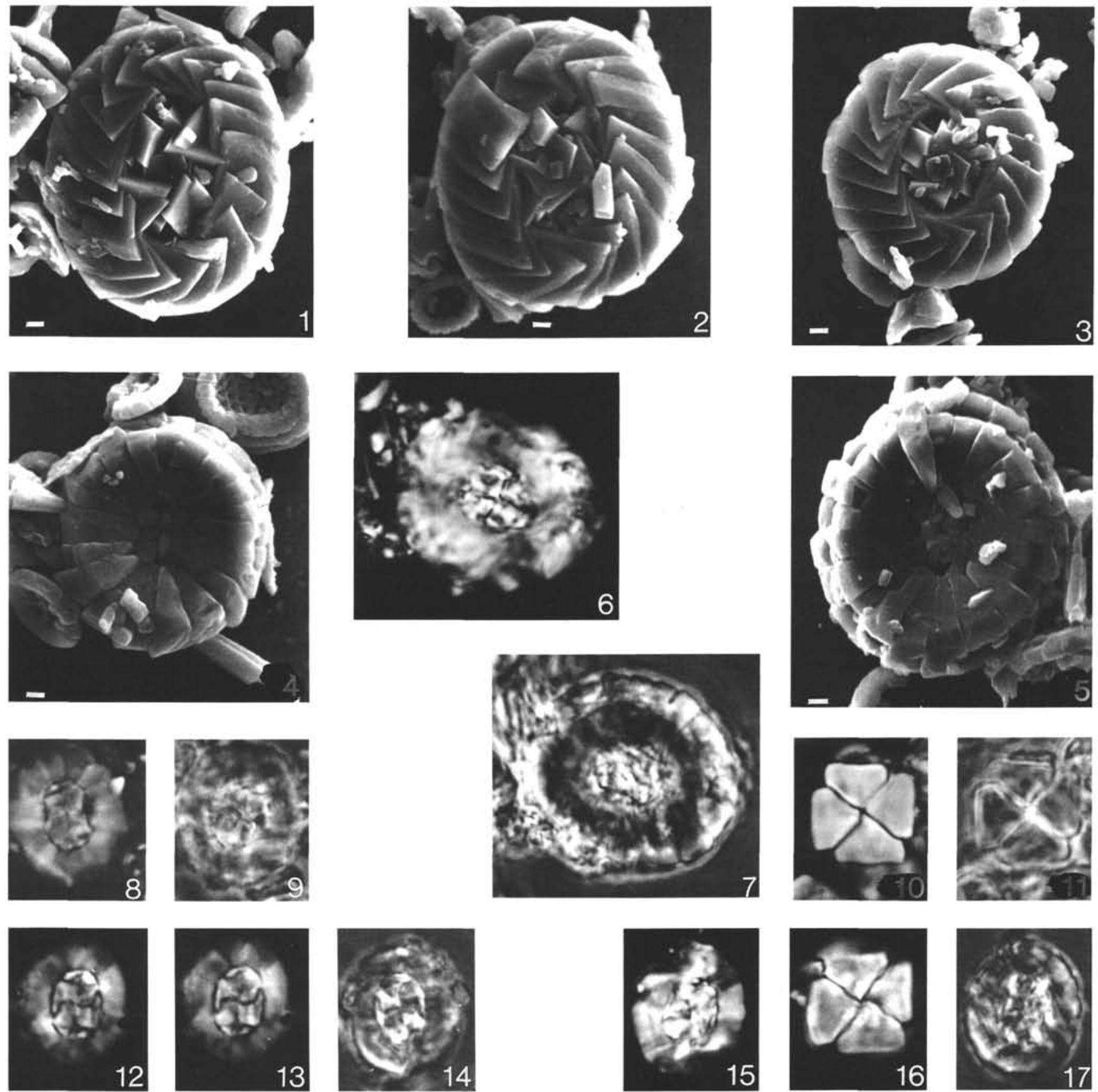

Plate 2. Ellipsagelosphaeraceae. 1-17. Petrarhabdus copulatus. (1) SEM, distal view; Sample 122-761B-24X-1, 39-40 cm. (2) SEM, distal view; Sample 122-761B-24X-1, 39-40 cm. (3) SEM, distal view; Sample 122-761B-24X-1, 39-40 cm. (4) SEM, proximal view; Sample 122-761B-24X-1, 39-40 cm. (5) SEM, proximal view; Sample 122-761B-24X-1, 39-40 cm. (6) Cross-polarized light; Sample 122-761B-24X-1, 39-40 cm. (7) Phase contrast, same specimen as (6). (8) Cross-polarized light; Sample 122-762C-52X-5, 129-131 cm. (9) Phase contrast, same specimen as (8). (10) Cross-polarized light; Sample 122-761B-25X-5, 43-44 cm. (11) Phase contrast, same specimen as (10). (12) Cross-polarized light; Sample 122-761B-25X-3, $42-43 \mathrm{~cm}$. (13) Cross-polarized light, same specimen as (12). (14) Phase contrast, same specimen as (12). (15) Cross-polarized light; Sample 122-761B-25X-3, 42-43 cm. (16) Cross-polarized light, same specimen as (15). (17) Phase contrast, same specimen as (16). Scale bar in scanning electron micrographs represents $1 \mu \mathrm{m}$. Light micrograph magnifications $2000 \times$. 

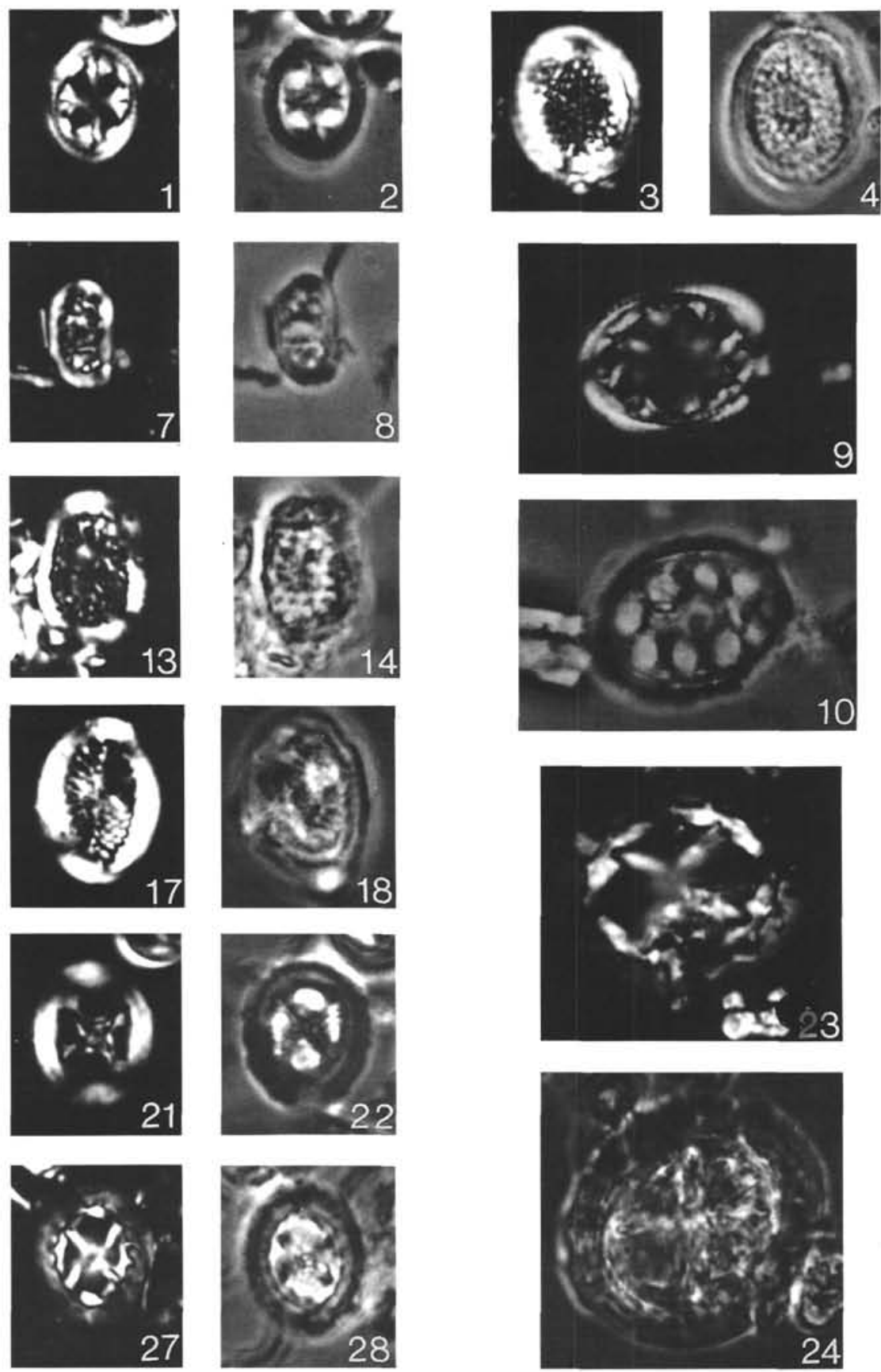

Plate 3. Light micrographs of Podorhabdaceae and Prediscosphaeraceae. 1, 2. Axopodorhabdus albianus. (1) Cross-polarized light, (2) phase contrast; Sample 122-763B-27X-2, 30-31 cm. 3, 4. Cribrosphaerella ehrenbergii. (3) Cross-polarized light, (4) phase contrast; Sample 122-761B-24X-3, 37-38 cm. 5, 6. Cribrosphaerella primitiva. (5) Cross-polarized light, (6) phase contrast; Sample 122-763B-23X-2, 30-31 cm. 7, 8. Nephrolithus frequens. (7) Cross-polarized light, (8) phase contrast; Sample 122-761B-21X-4, 129-130 cm. 9, 10. Octocyclus magnus. (9) Cross-polarized light, (10) phase contrast; Sample 122-763B-34X-2, 30-32 cm. 11, 12. Flabellites oblongus. (11) Cross-polarized light, (12) phase contrast; Sample 122-763B-32X-6, 30-31 cm. 13, 14. Nephrolithus corystus. (13) Cross-polarized light, (14) phase contrast; Sample 122-762C-49X-2, 30-32 cm. 15, 16. Cretarhabdus schizobrachiatus. (15) Cross-polarized light, (16) phase contrast; Sample 122-761B-23X-1, $81-83 \mathrm{~cm} .17,18$. Cretarhabdus loriei. (17) Cross-polarized light, (18) phase contrast; Sample 122-763B-25X-5, 43-44 cm. 19, 20. Cretarhabdus angustiforatus. (19) Cross-polarized light, (20) phase contrast; Sample 122-763B-32X-1, 30-31 cm. 21, 22. Cretarhabdus coronadventis. (21) Cross-polarized light, (22) phase contrast; Sample 122-763B-32X-6, 30-31 cm. 23, 24. Prediscosphaera grandis. (23) Cross-polarized light, (24) phase contrast; Sample 122-761B-21X-CC. 25, 26. Prediscosphaera arkhangelskyi. (25) Cross-polarized light, (26) phase contrast; Sample 122-762C-48X-CC. 27, 28. Prediscosphaera cretacea. (27) Cross-polarized light, (28) phase contrast; Sample 122-762C-54X-1, 30-31 cm. 29, 30. Prediscosphaera spinosa. (29) Cross-polarized light, (30) phase contrast; Sample 122-763B-23X-4, 30-31 $\mathrm{cm}$. All magnifications $2000 \times$. All phase contrast illustrations are of same specimen as previous cross-polarized plate. 

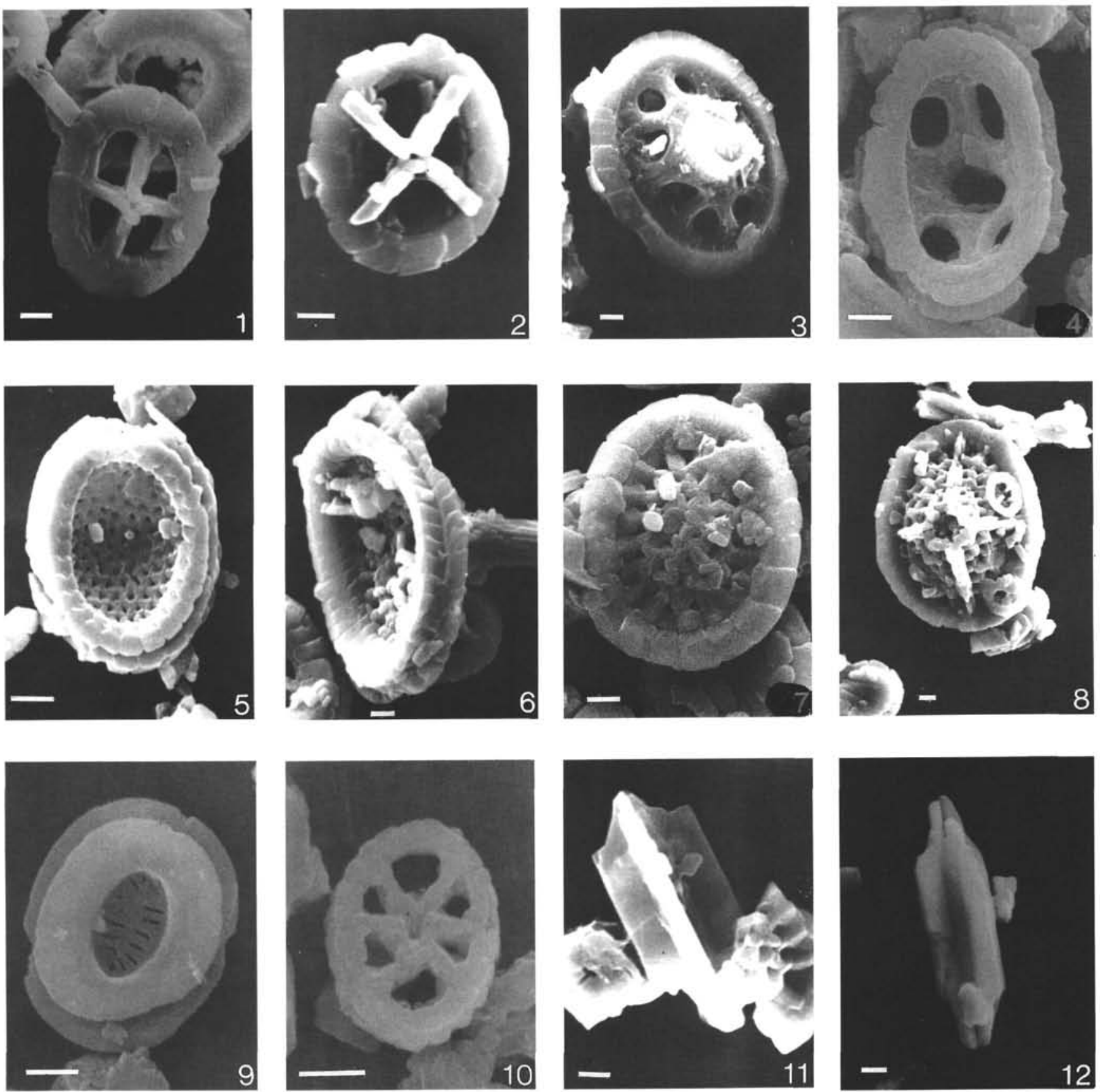

Plate 4. Scanning electron micrographs of various families. 1. Prediscosphaera spinosa. Distal view; Sample 122-761C-3R-5, 112-113 cm. 2. Prediscosphaera cretacea. Distal view; Sample 122-761C-3R-5, 112-113 cm. 3. Octocyclus magnus. Distal view; Sample 122-763B-30X-CC. 4. Axopodorhabdus albianus. Proximal view; Sample 122-763B-30X-CC. 5-7. Cribrosphaerella ehrenbergii. (5) Proximal view, (6) oblique proximal view, (7) distal view; Sample 122-761B-24X-1, 39-40 cm. 8. Cretarhabdus conicus. Distal view; Sample 122-761B-24X-1, 39-40 cm. 9. Cretarhabdus surirellus. Proximal view; Sample 122-763B-30X-CC. 10. Corollithion ellipticum. Sample 122-763B-30X-CC. 11. Lithraphidites quadratus. Sample $122-761$ C-3R-5, 112-113 cm. 12. Lithraphidites praequadratus. Sample $122-761 C-3 R-5,112-113 \mathrm{~cm}$. Scale bar represents $1 \mu \mathrm{m}$. 

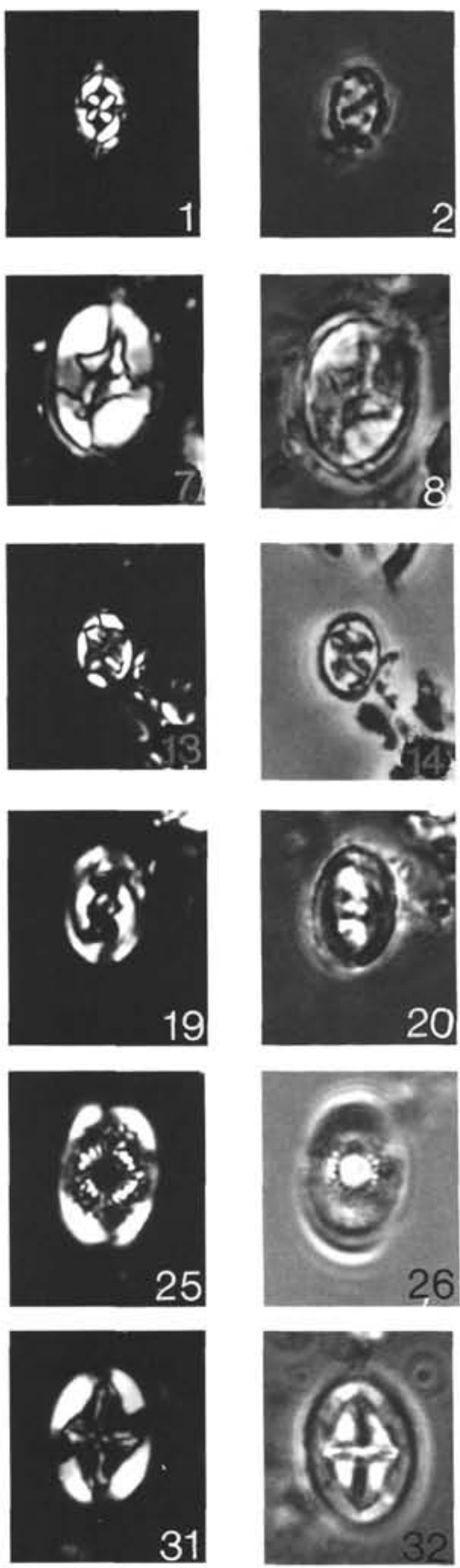
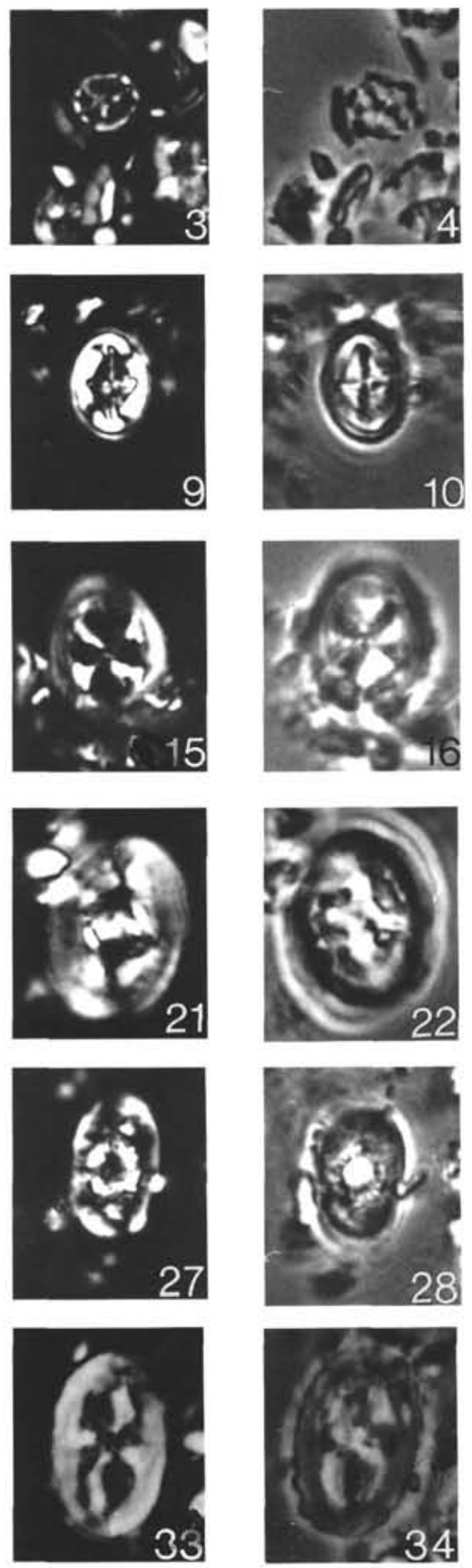
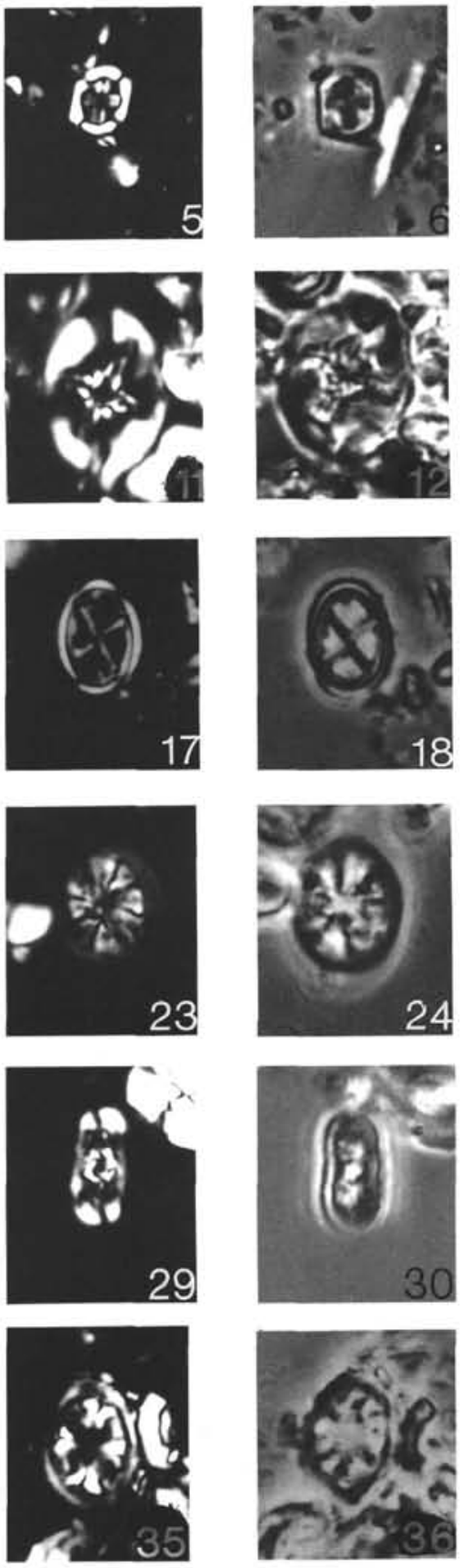

Plate 5. Light micrographs of Stephanolithionaceae, Eiffellithaceae, and Zygodiscaceae. 1, 2. Corollithion madagaskarensis. (1) Crosspolarized light, (2) phase contrast; Sample 122-761B-22X-2, 40-41 cm. 3, 4. Corollithion exiguum. (3) cross-polarized light, (4) phase contrast; Sample 122-762C-50X-5, 30-31 cm. 5, 6. Corollithion kennedyi. (5) Cross-polarized light, (6) phase contrast; Sample 122-763B-24X-1, 30-31 $\mathrm{cm}$. 7, 8. Eiffellithus eximius. (7) Cross-polarized light, (8) phase contrast; Sample 122-761B-25X-CC. 9, 10. Eiffellithus cf. E. eximius. (9) Cross-polarized light, (10) phase contrast; Sample 122-763B-32X-6, 30-31 cm. 11, 12. Eiffellithus turriseiffelii. (11) Cross-polarized light, (12) phase contrast; Sample 122-761B-24X-5, 34-35 cm. 13, 14. Eiffellithus trabeculatus. (13) Cross-polarized light, (14) phase contrast; Sample 122-762C-47X-4, 19-21 cm. 15, 16. Chiastozygus garrisonii. (15) Cross-polarized light, (16) phase contrast; Sample 122-762C-52X-4, 30-32 cm. 17, 18. Chiastozygus amphipons. (17) Cross-polarized light, (18) phase contrast; Sample 122-762C-50X-CC. 19, 20. Zygodiscus spiralis. (19) Cross-polarized light, (20) phase contrast; Sample 122-761B-21X-5, 61-62 cm. 21, 22. Reinhardtites anthophorus. (21) Cross-polarized light, (22) phase contrast; Sample 122-761B-25X-3, 42-43 cm. 23, 24. Parhabdolithus regularis. (23) Cross-polarized light, (24) phase contrast; Sample 122-761B-22X-1, 40-41 cm. 25, 26. Parhabdolithus asper. (25) Cross-polarized light, (26) phase contrast; Sample 122-763B-32X-6, $30-31 \mathrm{~cm}$. 27, 28. Parhabdolithus splendens. (27) Cross-polarized light, (28) phase contrast; Sample 122-763B-24X-6, 28-29 cm. 29, 30. Parhabdolithus angustus. (29) Cross-polarized light, (30) phase contrast; Sample 122-763B-32X-6, 30-31 cm. 31, 32. Vagalapilla matalosa. (31) Cross-polarized light, (32) phase contrast; Sample 122-763B-37X-4, 27-28 cm. 33, 34. Vagalapilla aachena. (33) Cross-polarized light, (34) phase contrast; Sample 122-762C-45X-5, 129-130 cm. 35, 36. Vagalapilla octoradiata. (35) Cross-polarized light, (36) phase contrast; Sample 122-762C-47X-4, 19-21 cm. All magnifications $2000 \times$. All phase contrast illustrations are of same specimen as previous cross-polarized plate. 

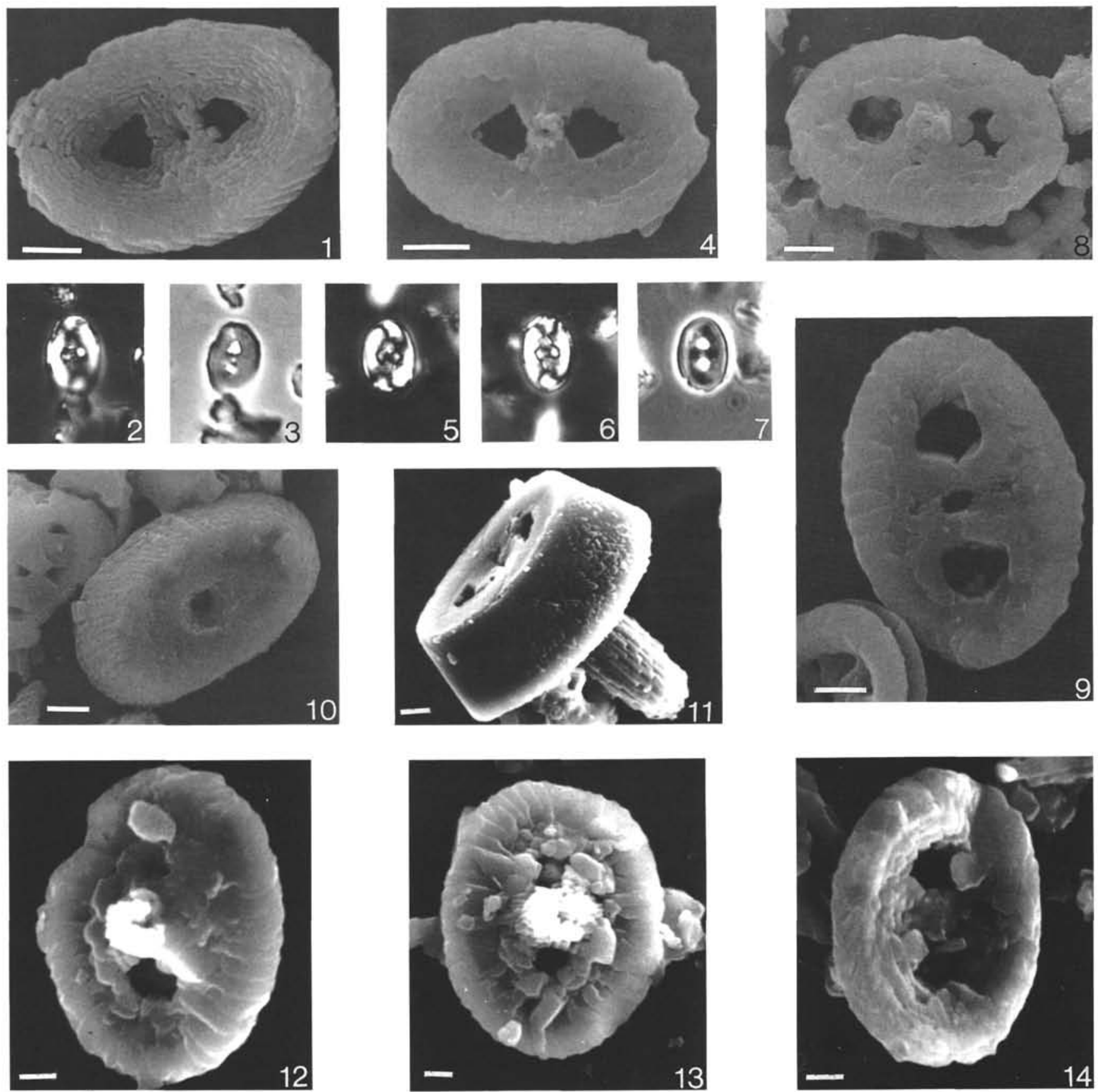

Plate 6. Scanning electron and light micrographs of Zygodiscaceae. 1-7. Percivalia hauxtonensis. Sample 122-763B-30X-CC. (1) SEM, proximal view, (2) cross-polarized light, same specimen as (1), (3) bright field, same specimen as (1), (4) SEM, distal view, (5) cross-polarized light, same specimen as (4), (6) cross-polarized light, same specimen as (4), and (7) phase contrast, same specimen as (4). 8, 9. Tranolithus orionatus. Sample 122-763B-30X-CC. (8) SEM, distal view, (9) SEM, proximal view. 10. Parhabdolithus asper. Proximal view, Sample 122-763B-30X-CC. 11. Parhabdolithus embergeri. Side view, Sample 122-763B-32X-6, 30-31 cm. 12-14. Reinhardtites anthophorus. Sample 122-762C-53X-3, 30-31 cm. (12) Distal view, (13) distal view, (14) proximal view. Scale bar in scanning electron micrographs represents $1 \mu \mathrm{m}$. Light micrograph magnifications $2000 \times$. 

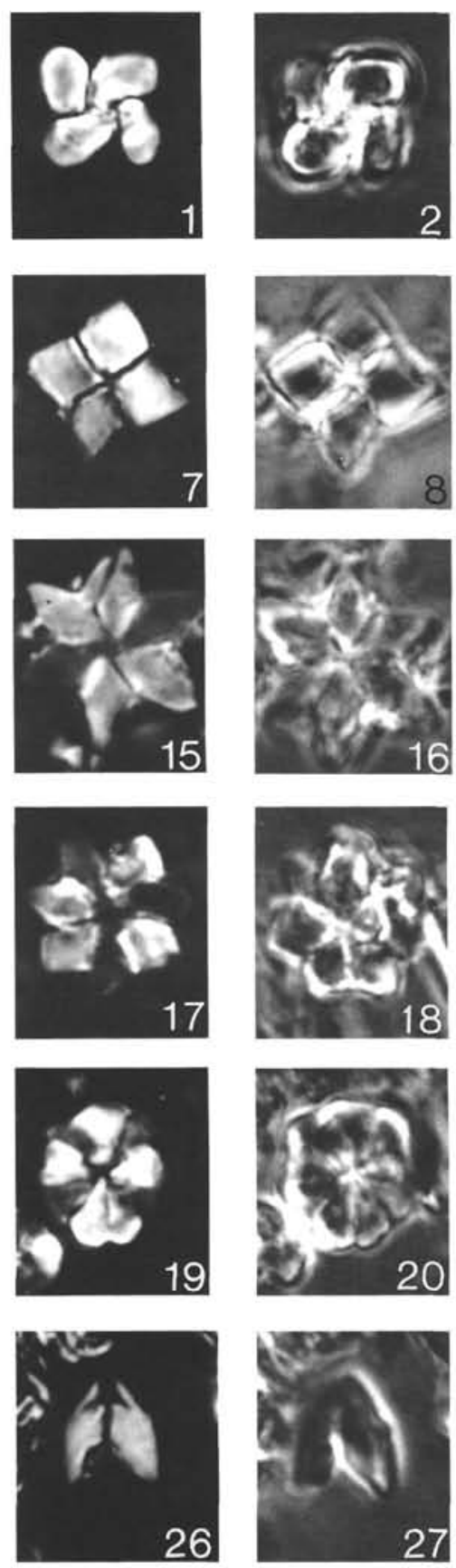
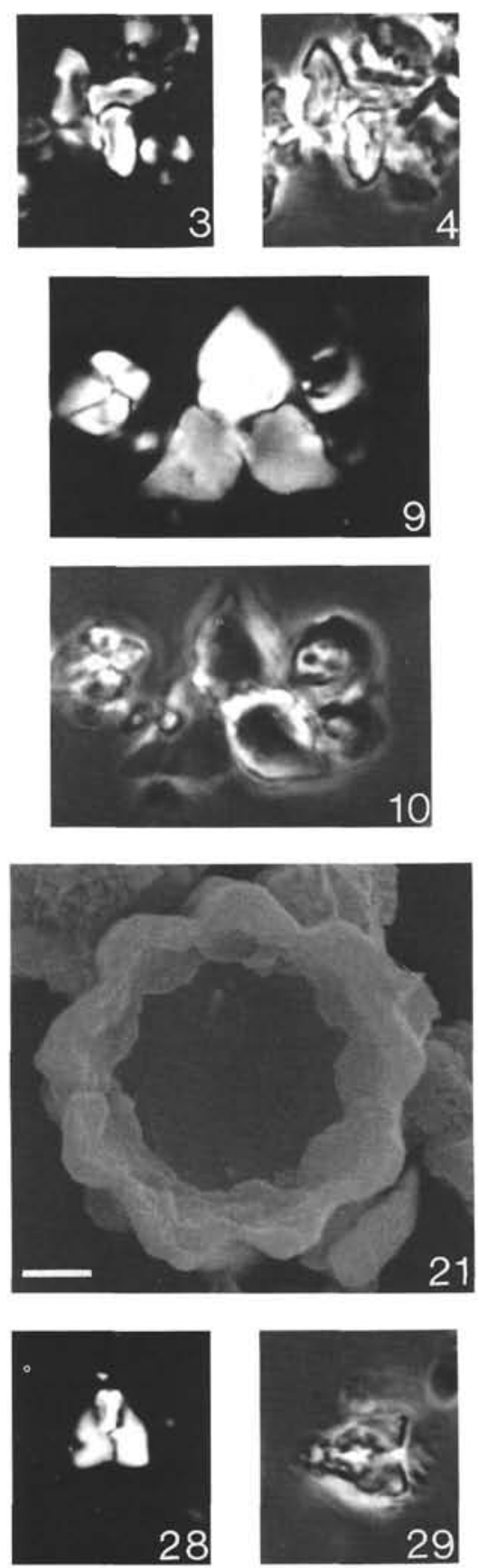

Plate 7. Light and scanning electron micrographs of Polycyclolithaceae and Incertae Sedis. 1, 2. Micula murus. (1) Cross-polarized light, (2) phase contrast; Sample 122-761B-21X-CC. 3, 4. Transitional M. murus/M. staurophora. (3) Cross-polarized light, (4) phase contrast; Sample 122-762C-44X-CC. 5, 6. Micula staurophora. (5) Cross-polarized light, (6) phase contrast; Sample 122-762C-50X-1, 124-125 cm. 7, 8. Quadrum gartneri. (7) Cross-polarized light, (8) phase contrast; Sample 122-761B-25X-1, 39-40 cm. 9, 10. Quadrum trifidum. (9) Cross-polarized light, (10) phase contrast; Sample 122-761B-25X-5, 43-44 cm. 11-14. Quadrum gothicum. (11, 13) Cross-polarized light, (12, 14) phase contrast; Sample 122-762C-49X-3, 30-32 cm. 15, 16. Lithastrinus grillii. (15) Cross-polarized light, (16) phase contrast; Sample 122-763B-16X-6, 30-31 cm. 17, 18. Eprolithus moratus. (17) Cross-polarized light, (18) phase contrast; Sample 122-762C-72X-CC. 19-21. Eprolithus floralis. (19) Cross-polarized light, (20) phase contrast; Sample 122-762-74X-CC. (21) Scanning electron micrograph; Sample 122-763B-30X-CC. 22, 23. Hayesites albiensis. (22) Cross-polarized light, (23) phase contrast; Sample 122-763B-34X-6, 30-32 cm. 24, 25. Zebrashapka sp. (24) Cross-polarized light, (25) phase contrast; Sample 122-763B-25X-5, 30-31 cm. 26-31. Ceratolithoides aculeus. (26, 28, 30) Cross-polarized light, $(27,29,31)$ phase contrast. (26, 27) Sample 122-761B-23X-3, 40-41 cm. (28-31) Sample 122-761B-22X-4, 80-82 cm. Scale bar in scanning electron micrograph represents $1 \mu \mathrm{m}$. Light micrograph magnifications $2000 \times$. 

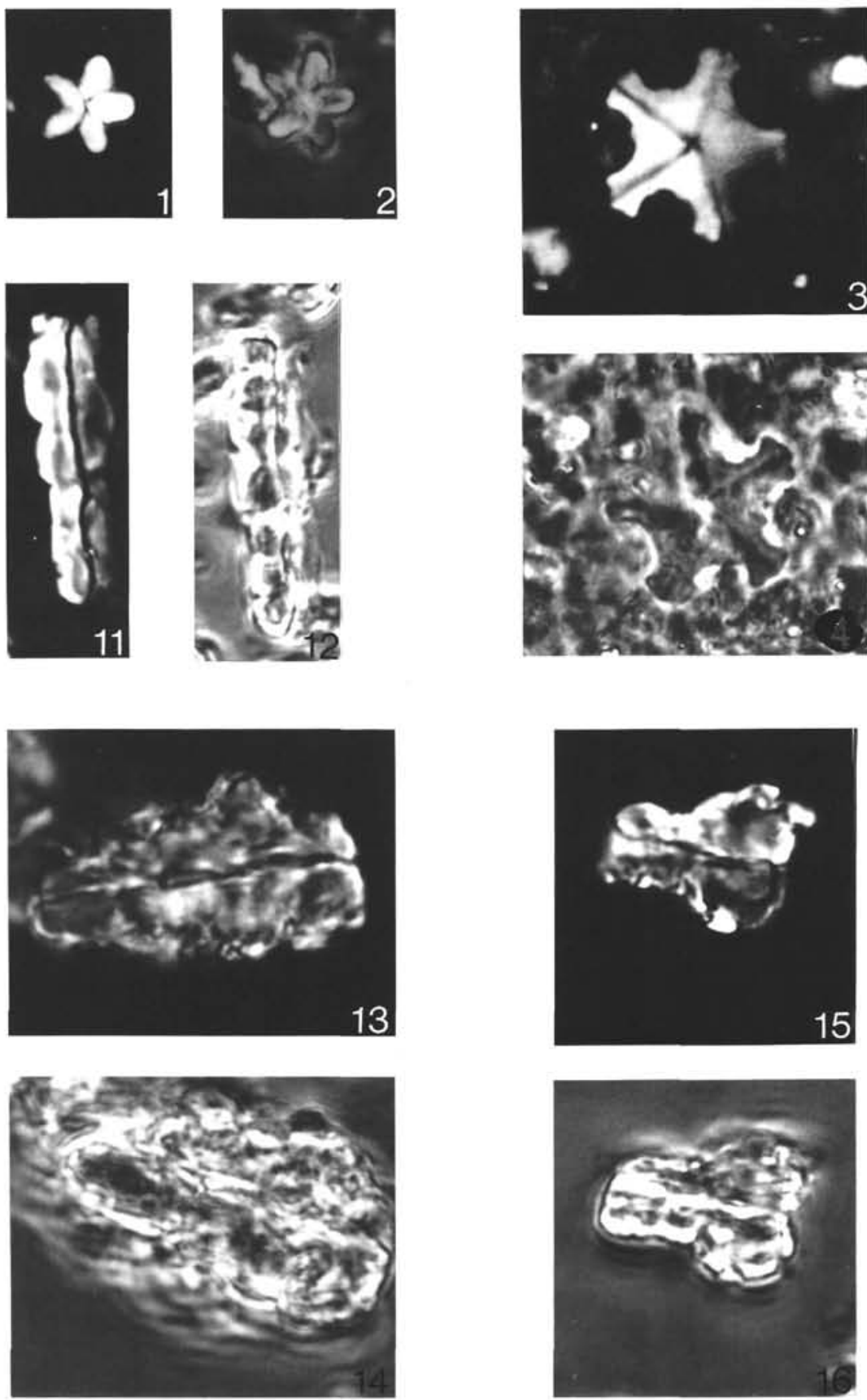
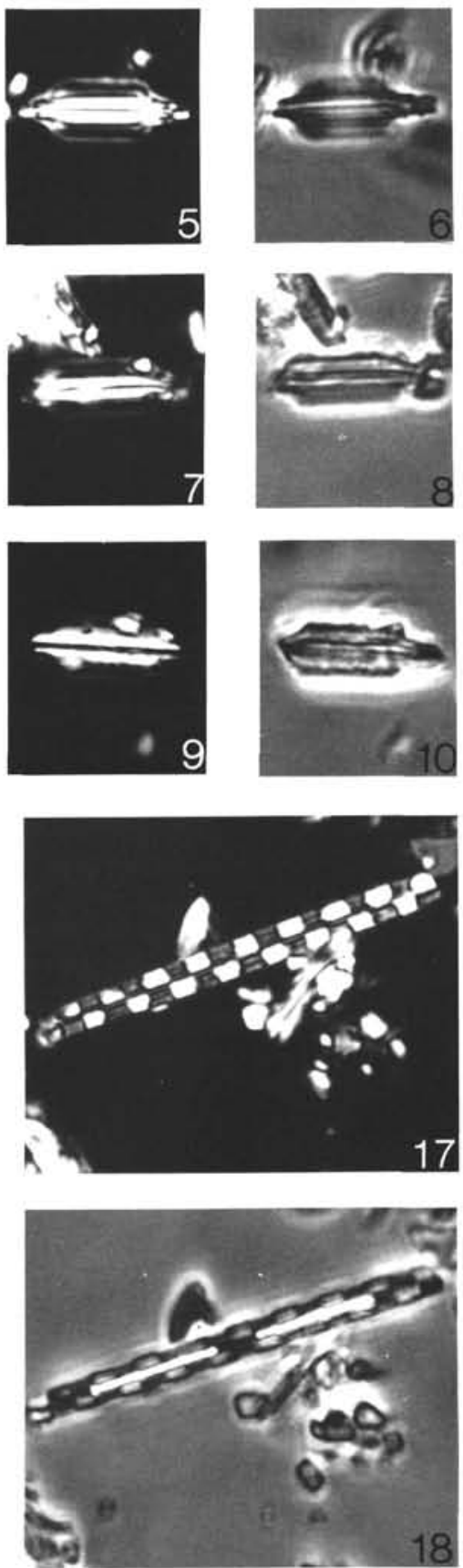

Plate 8. Light micrographs of Braarudosphaeraceae, Calyptrosphaeraceae, and Microrhabdulaceae. 1, 2. Braarudosphaera stenorheta. (1) Cross-polarized light, (2) phase contrast; Sample 122-763B-32X-2, 30-31 cm. 3, 4. Micrantholithus brevis. (3) Cross-polarized light, (4) phase contrast; Sample 122-763C-21X-6, 29-30 cm. 5, 6. Lithraphidites quadratus. (5) Cross-polarized light, (6) phase contrast; Sample 122-761B-21X-5, 61-62 cm. 7-10. Lithraphidites praequadratus. (7, 9) Cross-polarized light, (8, 10) phase contrast; (7, 8) Sample 122-762C-44X-3, 129-130 cm; (9, 10) Sample 122-761B-22X-2, 40-41 cm. 11-14. Lucianorhabdus cayeuxii. (11, 13) Cross-polarized light, (12, 14) phase contrast; Sample 122-762C-61X-CC. 15, 16. Lucianorhabdus maleformis. (15) Cross-polarized light, (16) phase contrast; Sample 122-762C-61X-CC. 17, 18. Microrhabdulus decoratus. (17) Cross-polarized light, (18) phase contrast; Sample 122-762C-69X-2, 30-32 cm. All magnifications $2000 \times$. All phase contrast illustrations are of same specimen as previous cross-polarized plate. 